\title{
Evaluation of the airborne quantum cascade laser spectrometer (QCLS) measurements of the carbon and greenhouse gas suite - $\mathrm{CO}_{2}, \mathrm{CH}_{4}, \mathrm{~N}_{2} \mathrm{O}$, and $\mathrm{CO}$ - during the CalNex and HIPPO campaigns
}

\author{
G. W. Santoni ${ }^{1}$, B. C. Daube ${ }^{1}$, E. A. Kort ${ }^{2}$, R. Jiménez ${ }^{3}$, S. Park ${ }^{4}$, J. V. Pittman ${ }^{1}$, E. Gottlieb ${ }^{1}$, B. Xiang ${ }^{1}$, \\ M. S. Zahniser ${ }^{5}$, D. D. Nelson ${ }^{5}$, J. B. McManus ${ }^{5}$, J. Peischl ${ }^{6}$, T. B. Ryerson ${ }^{7}$, J. S. Holloway ${ }^{7}$, A. E. Andrews ${ }^{7}$, \\ C. Sweeney $^{6}$, B. Hall ${ }^{7}$, E. J. Hintsa ${ }^{6,7}$, F. L. Moore ${ }^{6,7}$, J. W. Elkins ${ }^{7}$, D. F. Hurst ${ }^{6,7}$, B. B. Stephens ${ }^{8}$, J. Bent ${ }^{9}$, and \\ S. C. Wofsy ${ }^{1}$ \\ ${ }^{1}$ Harvard University, School of Engineering and Applied Sciences and Department of Earth and Planetary Sciences, \\ Cambridge, Massachusetts, USA \\ ${ }^{2}$ University of Michigan, College of Engineering, Department of Atmospheric, Oceanic and Space Sciences, Ann Arbor, \\ Michigan, USA \\ ${ }^{3}$ Universidad Nacional de Colombia - Bogota, Department of Chemical and Environmental Engineering, Bogota, Colombia \\ ${ }^{4}$ Department of Oceanography, College of Ecology and Environmental Science, Kyungpook National University, \\ Sangju, Korea \\ ${ }^{5}$ Aerodyne Research, Inc., Center for Atmospheric and Environmental Chemistry, Billerica, Massachusetts, USA \\ ${ }^{6}$ Cooperative Institute for Research in Environmental Sciences, University of Colorado, Boulder, Colorado, USA \\ ${ }^{7}$ Earth System Research Laboratory, National Ocean and Atmospheric Administration, Boulder, Colorado, USA \\ ${ }^{8}$ National Center for Atmospheric Research, Earth Observing Laboratory, Boulder, Colorado, USA \\ ${ }^{9}$ Scripps Institution of Oceanography, La Jolla, California, USA \\ Correspondence to: G. W. Santoni (gsantoni@gmail.com)
}

Received: 7 October 2013 - Published in Atmos. Meas. Tech. Discuss.: 13 November 2013

Revised: 4 March 2014 - Accepted: 10 March 2014 - Published: 2 June 2014

\begin{abstract}
We present an evaluation of aircraft observations of the carbon and greenhouse gases $\mathrm{CO}_{2}, \mathrm{CH}_{4}, \mathrm{~N}_{2} \mathrm{O}$, and $\mathrm{CO}$ using a direct-absorption pulsed quantum cascade laser spectrometer (QCLS) operated during the HIPPO and CalNex airborne experiments. The QCLS made continuous $1 \mathrm{~Hz}$ measurements with $1 \sigma$ Allan precisions of 20, 0.5, 0.09, and $0.15 \mathrm{ppb}$ for $\mathrm{CO}_{2}, \mathrm{CH}_{4}, \mathrm{~N}_{2} \mathrm{O}$, and $\mathrm{CO}$, respectively, over $>500$ flight hours on 79 research flights. The QCLS measurements are compared to two vacuum ultraviolet (VUV) $\mathrm{CO}$ instruments (CalNex and HIPPO), a cavity ring-down spectrometer (CRDS) measuring $\mathrm{CO}_{2}$ and $\mathrm{CH}_{4}$ (CalNex), two broadband non-dispersive infrared (NDIR) spectrometers measuring $\mathrm{CO}_{2}$ (HIPPO), two onboard gas chromatographs measuring a variety of chemical species including $\mathrm{CH}_{4}, \mathrm{~N}_{2} \mathrm{O}$, and $\mathrm{CO}$ (HIPPO), and various flask-based measurements of
\end{abstract}

all four species. QCLS measurements are tied to NOAA and WMO standards using an in-flight calibration system, and mean differences when compared to NOAA CCG flask data over the 59 HIPPO research flights were 100, 1, 1, and $2 \mathrm{ppb}$ for $\mathrm{CO}_{2}, \mathrm{CH}_{4}, \mathrm{~N}_{2} \mathrm{O}$, and $\mathrm{CO}$, respectively. The details of the end-to-end calibration procedures and the data quality assurance and quality control (QA/QC) are presented. Specifically, we discuss our practices for the traceability of standards given uncertainties in calibration cylinders, isotopic and surface effects for the long-lived greenhouse gas tracers, interpolation techniques for in-flight calibrations, and the effects of instrument linearity on retrieved mole fractions. 


\section{Introduction}

Growing interest in understanding the drivers of climate change has sparked innovation in instrumentation to measure long-lived greenhouse gases and associated chemical tracers (Chen et al., 2010; Fried et al., 2009; Nelson et al., 2004; O'Shea et al., 2013; Xiang et al., 2013a; Zahniser et al., 2009; Zare et al., 2009). The improvements in measurement precision and ease of use must be matched with a corresponding increase in calibration efforts to achieve comparable gains in compatibility. Many sensors rely on the accuracy of spectroscopic parameters (e.g., line strengths and their pressure and temperature dependencies) to derive in situ "spectroscopically calibrated" mixing ratios from raw spectra (Rothman et al., 2009; Zahniser et al., 1995). The use of these raw data is often appropriate, particularly if (1) a sensor is linear with respect to the range of observed concentrations, and (2) the quantity of interest is the relative enhancement of one chemical tracer versus another or versus background values measured on the same sensor. More and more studies, however, are incorporating data from different sensors (Gerbig et al., 2003; Zhao et al., 2009; Xiang et al., 2013b; Miller et al., 2008). It is in this context that spectroscopically calibrated mixing ratios are insufficient, as small differences in sensor accuracies can have large effects, for example, on inversion studies.

Here we discuss the traceability of airborne in situ spectrometer measurements. We present an overview of the quantum cascade laser spectrometer (QCLS) sensor used on two airborne campaigns - the HIAPER Pole-to-Pole Observations (HIPPO; Wofsy et al., 2011) campaign on the NCAR HIAPER-GV and the California Research at the Nexus of Air Quality and Climate Change experiment (CalNex; Ryerson et al., 2012) on the NOAA P-3 - and present measurement comparisons with other onboard sensors and flask samplers. We describe operations of the QCLS and the calibrations of the carbon and greenhouse-gas measurements of $\mathrm{CO}_{2}$, $\mathrm{CH}_{4}, \mathrm{~N}_{2} \mathrm{O}$, and $\mathrm{CO}$. We evaluate the traceability of calibration standards from the World Meteorological Organization (WMO) and National Oceanic and Atmospheric Administration (NOAA) calibrated values to the in-flight standards as well as long-term sensor stability. We then characterize the in-flight drift through interpolations to periodic sample replacements with calibrated air and discuss how this affects our overall accuracy. In the context of traceability and sensor accuracy, we discuss sample conditioning, surface equilibration effects, and isotopic effects on calibration standards.

\section{Quantum cascade laser spectrometer}

\subsection{QCLS hardware}

This work focuses on data collected using the Harvard/NCAR/Aerodyne Research Inc. quantum cascade laser spectrometer (QCLS). To the extent they are needed in explaining the traceability of our measurements, we briefly describe the instrument characteristics, noting that more details of the spectrometer are available in Jiménez et al. (2005, 2006). The QCLS uses three pulsed quantum cascade lasers to measure $\mathrm{CO}_{2}, \mathrm{CH}_{4}, \mathrm{~N}_{2} \mathrm{O}$, and $\mathrm{CO}$ by absorption spectroscopy. One laser (QCL1, $\sim 2319 \mathrm{~cm}^{-1}$ ) is used as a light source for a differential absorption measurement of $\mathrm{CO}_{2}$ by recording the difference between a sample absorption spectrum and the absorption spectrum of a calibrated standard flowing through a separate reference cell. The remaining two lasers, housed in a second optical compartment, are tuned across absorption lines for $\mathrm{CH}_{4}$ and $\mathrm{N}_{2} \mathrm{O}$ in one scan (QCL2, $\sim 1275 \mathrm{~cm}^{-1}$ ), and CO in another (QCL3, $\sim 2169 \mathrm{~cm}^{-1}$ ), making use of a multi-pass astigmatic sample cell to increase the effective optical path length (McManus et al., 1995). Laser beams from QCL2 and QCL3 are co-aligned through an anchor point before being directed into the sample multipass cell. The light pulses from the three QCLs are detected using photovoltaic detectors housed and cooled in two liquid nitrogen $\left(\mathrm{LN}_{2}\right)$ dewars: one for $\mathrm{CO}_{2} / \mathrm{QCL} 1$ and the other for both $\mathrm{CH}_{4} / \mathrm{N}_{2} \mathrm{O} / \mathrm{QCL} 2$ and CO/QCL3. The $\mathrm{CO}_{2}$ optical table, QCL1, two $10 \mathrm{~cm}$ path length sampling cells, and a dewar housing InSb detectors for the $\mathrm{CO}_{2}$ portion of the QCLS are enclosed in a temperature-controlled pressure vessel flushed with ultra-high-purity nitrogen to remove the effects of absorption external to the sampling cells. QCL2 and QCL3, an astigmatic multi-pass sampling cell with an effective $76 \mathrm{~m}$ path length, and a dewar housing the $\mathrm{HgCdTe}$ detectors are mounted on a second optical table surrounded by a temperature-regulated enclosure. The pulses from QCL2 and QCL3 are temporally multiplexed on the same pair of detectors.

The spectra acquired from the two optical tables are controlled and analyzed by the same computer. TDL Wintel ${ }^{\circledR}$ software controls the laser temperature and overall output frequency, the tuning ramp rate (the wavelength frequency range and rate over which the laser is tuned) and the detector multiplexing for QCL2 and QCL3, which share a pair of common detectors. The temperature regulation of the QCLs is achieved by means of Peltier modules coupled to a closedcircuit recirculating fluid kept at fixed temperature within $288.0 \pm 0.1 \mathrm{~K}$. With the exception of the chiller fluid, electronics and computer, the $\mathrm{CO}_{2}$ measurement (QCLS-CO2) can be considered independent from the $\mathrm{CH}_{4}, \mathrm{~N}_{2} \mathrm{O}$, and $\mathrm{CO}$ measurements (QCLS-DUAL), and we refer to those two sensors as such.

The instrument is fully autonomous, and sampling, calibration, temperature regulation, and pressure regulation are controlled by a data logger (CR10X, Campbell Scientific). It logs control variables and periodically dumps them via a serial connection to the computer running TDL Wintel ${ }^{\circledR}$ for storage on a solid-state hard drive. Because the sampling and control strategy is controlled by the data logger and the 

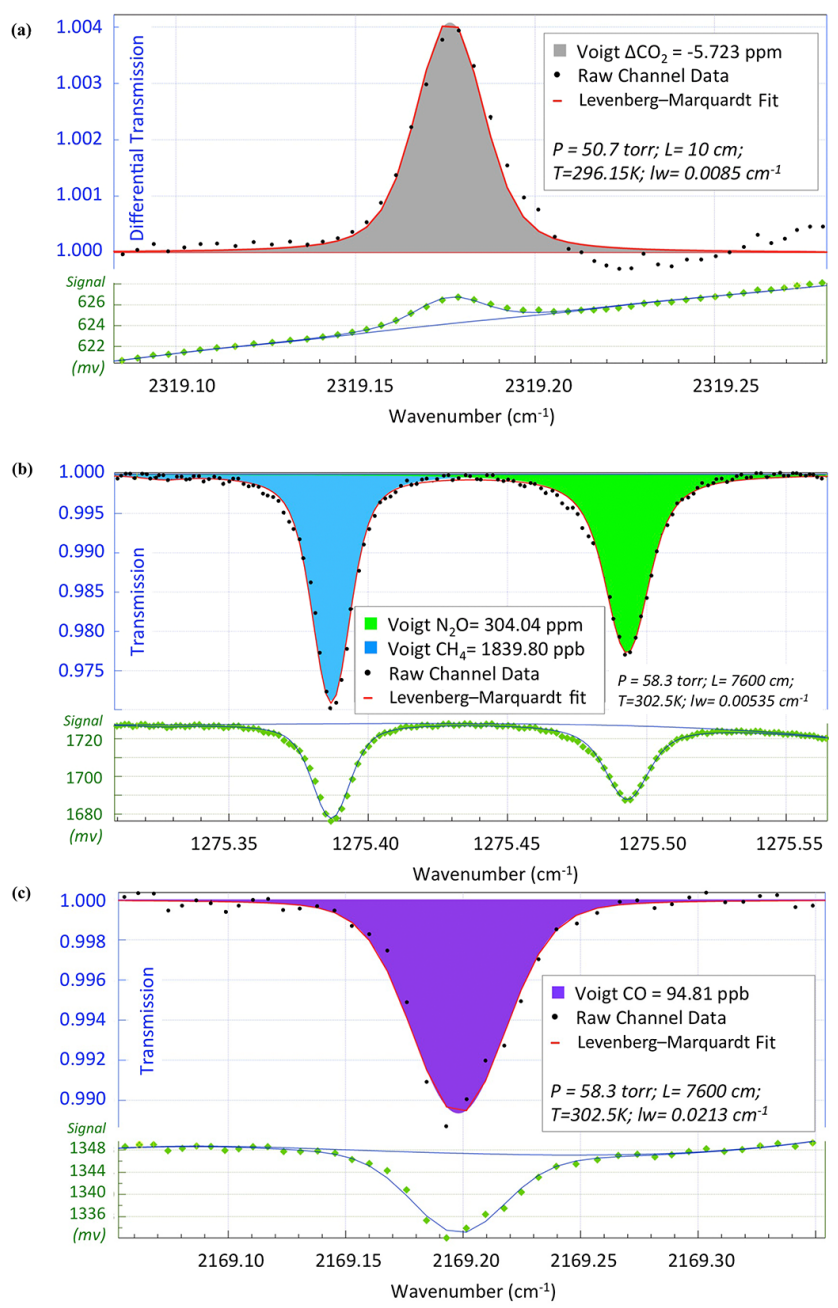

Figure 1. Absorption spectra for the three quantum cascade lasers. QCL1 (a) is a differential measurement of ${ }^{12} \mathrm{CO}_{2}$ and therefore appears inverted because this sample has a lower concentration of $\mathrm{CO}_{2}$ than the reference gas. QCL2 (b) shows the spectrum for $\mathrm{CH}_{4}$ and $\mathrm{N}_{2} \mathrm{O}$ and QCL3 (c) shows the spectrum for CO. The sample pressure $(P)$, effective path length $(L)$, sample temperature $(T)$, and laser line width (lw) are listed for each sample spectrum.

spectral analysis is performed by the TDL Wintel ${ }^{\circledR}$ software running on the computer, in-flight spectra are acquired using a fixed nominal cell pressure and cell temperature. Raw spectra are later reanalyzed with the logged CR10 cell pressure and cell temperature measurements to generate spectroscopically calibrated mixing ratios. Figure 1 shows the raw spectra and the Levenberg-Marquardt fits to the absorption lines within the scan according to the HITRAN database (Rothman et al., 2009) for the three QCLs. The $\mathrm{CO}_{2}$ spectrum appears inverted because this particular air sample has less $\mathrm{CO}_{2}$ than the calibration air flowing through the reference cell.

Optical-based measurements are particularly sensitive to fluctuations in temperature and pressure (Zahniser et al.,
1995) and careful controls must be implemented, particularly during flight where large dynamic ranges in both variables are observed (Fried et al., 2009). In-flight calibrations at regular intervals from gas cylinders are used to track sensor drift. As long as the inter-calibration time interval is shorter than the long-term drift, standard additions can offset inaccuracies due to pressure and temperature fluctuations. The Allan variance, a measure of the precision of a sensor as a function of averaging time (Werle et al., 1993), can be used to quantify both the short-term (e.g., electronic noise) and long-term precision of a sensor as well as the drift. Figure 2 shows the inflight Allan variance for the $\mathrm{CO}_{2}, \mathrm{CH}_{4}, \mathrm{~N}_{2} \mathrm{O}$, and $\mathrm{CO}$ measurements from the QCLS with $1 \mathrm{~s}$ RMS precisions (Allan standard deviations) of 20,0.5, 0.09, and $0.15 \mathrm{ppb}$, respectively. The measurements shown in Fig. 2 were taken during a section of HIPPO that sampled a relatively constant air mass above the remote Pacific Ocean. This is the same section of data presented in the supplementary material section of Kort et al. (2011). Table 1 summarizes the Allan precisions at 1,10 , and $100 \mathrm{~s}$ for the four species. During flight sampling, the Allan precision between 1 and $10 \mathrm{~s}$ improves for all species, but only continues to improve between 10 and $100 \mathrm{~s}$ for $\mathrm{N}_{2} \mathrm{O}$. This is largely because atmospheric variability in $\mathrm{CO}_{2}, \mathrm{CH}_{4}$, and $\mathrm{CO}$ is larger relative to $\mathrm{N}_{2} \mathrm{O}$ as the atmospheric lifetime of $\mathrm{N}_{2} \mathrm{O}$ is $\sim 118$ years (Hsu and Prather, 2010) and the sources are more spatially uniform than for the other species. Because of this, Table 1 also includes the Allan precision from laboratory tests that sampled air continuously flowing from calibration cylinders with near-ambient atmospheric concentrations.

The flow schematics for QCLS-CO2 are shown in Fig. 3. The two schematics are very similar. QCLS-CO2 and QCLSDUAL have independent inlets. On the HIAPER-GV, both inlets extend out from the QCLS rack to a dedicated NCAR HIAPER Modular Inlet (HIMIL) mounted to the edge of the aircraft. The HIMIL extends the inlet $28 \mathrm{~cm}$ from the body of the aircraft (NCAR, 2005); the two QCLS inlets, both 316 stainless steel $0.25^{\prime \prime} \mathrm{OD}$, sample from within the center flow path, oriented away from the direction of flow (i.e., rear-facing). This orientation minimizes large particle entrainment and protects the sampling system from liquid water and ice. For the NOAA P-3 aircraft, the inlets both consist of stainless steel 3/8" OD tubing bent at 90 degrees to be parallel to the aircraft and oriented at -135 degrees relative to the horizontal direction of flight. Once the sample enters the body of both aircraft, the two sample lines consist of $\sim 1.5 \mathrm{~m}$ of Synflex type 1300 tubing $\left(6.35 \mathrm{~mm}=1 / 4^{\prime \prime}\right.$ OD for QCLS-CO2 and $9.525 \mathrm{~mm}=3 / 8^{\prime \prime}$ OD for QCLSDUAL), and each sample stream reaches a $2 \mu \mathrm{m}$ filter $(47 \mathrm{~mm}$ OD Pall Zefluor membrane) mounted on an aluminum filter holder (Gelman Sciences, Inc., Rossdorf, Germany). Calibration gases are added downstream of the filter using a combination of two-way and three-way solenoid valves. When activated, the solenoid valves allow air from two sets of calibration gas decks, which each include three cylinders $(1.1 \mathrm{~L}$ 
Table 1. Allan precision as a function of averaging time for the four QCLS species measured during the in-flight sampling of a relatively constant air mass on HIPPO II, 22 October 2009 ("flight"), and during laboratory testing sampling continuously from a secondary calibration cylinder ("lab"). Accuracy estimates are based on the accuracy of the NOAA primary cylinders, where accuracy in this context is an estimate of how well the scale can be transferred to different instruments or laboratories at near-ambient mole fractions.

\begin{tabular}{|c|c|c|c|c|c|c|c|}
\hline \multirow[b]{3}{*}{ Species } & \multicolumn{6}{|c|}{$1 \sigma$ Allan Precision (ppb) } & \multirow[b]{3}{*}{ Accuracy $(\mathrm{ppb})$} \\
\hline & \multicolumn{2}{|c|}{$1 \mathrm{~s}$} & \multicolumn{2}{|c|}{$10 \mathrm{~s}$} & \multicolumn{2}{|c|}{$100 \mathrm{~s}$} & \\
\hline & flight & lab & flight & lab & flight & lab & \\
\hline $\mathrm{CO}_{2}$ & 20. & 13 & 20. & 2.3 & 27 & 1.7 & 100 \\
\hline $\mathrm{CH}_{4}$ & 0.52 & 0.50 & 0.28 & 0.18 & 0.47 & 0.09 & 1 \\
\hline $\mathrm{N}_{2} \mathrm{O}$ & 0.089 & 0.080 & 0.037 & 0.038 & 0.021 & 0.024 & 0.2 \\
\hline $\mathrm{CO}$ & 0.15 & 0.15 & 0.15 & 0.041 & 0.24 & 0.018 & 3.5 \\
\hline
\end{tabular}

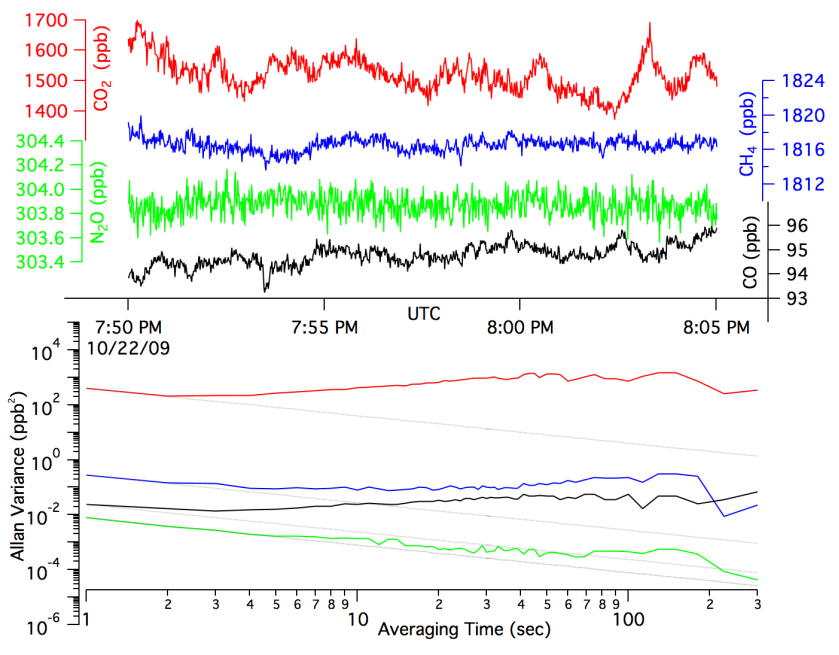

Figure 2. Time series for the four QCLS species during $20 \mathrm{~min}$ of in-flight sampling over the Pacific during HIPPO II (top) and the Allan variance as a function of averaging time for the data shown (bottom). Table 1 summarizes these data and also provides corresponding values for sampling from a calibration cylinder in the laboratory. All concentrations are reported in units of ppb, including $\mathrm{CO}_{2}$, which is the concentration relative to the reference concentration. In this plot, the $\mathrm{CO}_{2}$ concentration is $\sim 1.5 \mathrm{ppm}$ above the reference gas concentrations of $\sim 390 \mathrm{ppm}$.

for QCLS-CO2 and 2.0 L for QCLS-DUAL) to "over-blow" the inlet, with the excess flow exiting the aircraft through the HIMIL. The regulators for the calibration cylinders are set on the ground to achieve an excess flow $>100 \mathrm{sccm}$ (QCLSCO2) or $>200 \mathrm{sccm}$ (QCLS-DUAL), which flows via the filters and inlets out of the aircraft. From this point, the sample (or calibration) air travels through a 1-tube (QCLS-CO2; see Daube et al., 2002, for an explanation of this choice) or 50-tube (QCLS-DUAL) Nafion membrane dryer to remove the bulk of the water vapor. Then the air passes through a Teflon dry-ice trap to further reduce the dew point to below $-70^{\circ} \mathrm{C}$. A stainless steel filter (Swagelok, SS-4FW-2, $2 \mu \mathrm{m}$ stainless steel mesh) at the outlet of the dry-ice trap ensures that particles cannot exit the trap, thaw, evaporate, and contaminate the measurement cell mirrors. From the dry ice trap, air enters the sample cells, the pressures of which are controlled both upstream and downstream of the cell using a pressure controller and valve (MKS 722, 100 torr range). For QCLS-CO2, the $9.7 \mathrm{~cm}^{3}$ sample cell is controlled to $70 \pm 0.1 \mathrm{hPa}$ using another MKS 722, and the reference cell pressure is matched using a differential pressure controller and valve (MKS 223B, 100 torr absolute, 10 torr differential range). For QCLS-DUAL, the $0.5 \mathrm{~L}$ cell is controlled to $77 \pm 0.1 \mathrm{hPa}$. After the pressure control element downstream of the sample cells, the flows are routed back through the outer tube enclosing the Nafion membrane tubes to create the necessary $\mathrm{H}_{2} \mathrm{O}$ gradient across the membrane. The flows are then combined into a four-stage diaphragm pump (KNF Neuberger, Inc. UN726) fitted with Teflon-lined diaphragms. Two of the heads are connected in parallel, and the remaining two downstream pumps are connected in series to compensate throughput and power. For the HIAPER-GV, the exhaust is then dumped to a dedicated exhaust manifold in the aircraft. For CalNex, the exhaust is dumped through a third stainless steel port downstream of the inlet.

Overall instrument response time is largely controlled by the sample cell pressure and volume, the flow rate, and the inlet pressure and volume. Additional lags associated with mixing within the different sampling volumes are secondorder effects, but are minimized by using $6.35 \mathrm{~mm}$ OD and $9.525 \mathrm{~mm}$ OD Synflex for QCLS-CO2 and QCLS-DUAL respectively. The larger diameter tubing is needed for QCLSDUAL because of the larger sample cell volume. The flow rates through QCLS-CO2 and QCLS-DUAL are 0.1 and $1.0 \mathrm{sLpm}$, respectively, which correspond to cell flushing times on the order of $1 \mathrm{~s}$ for both sensors, assuming plug flow.

\subsection{QCLS traceability}

In-flight calibrations are done by replacing air in the sample cell with air from compressed gas cylinders in two gas decks mounted on the QCLS flight rack (see Fig. 3). 

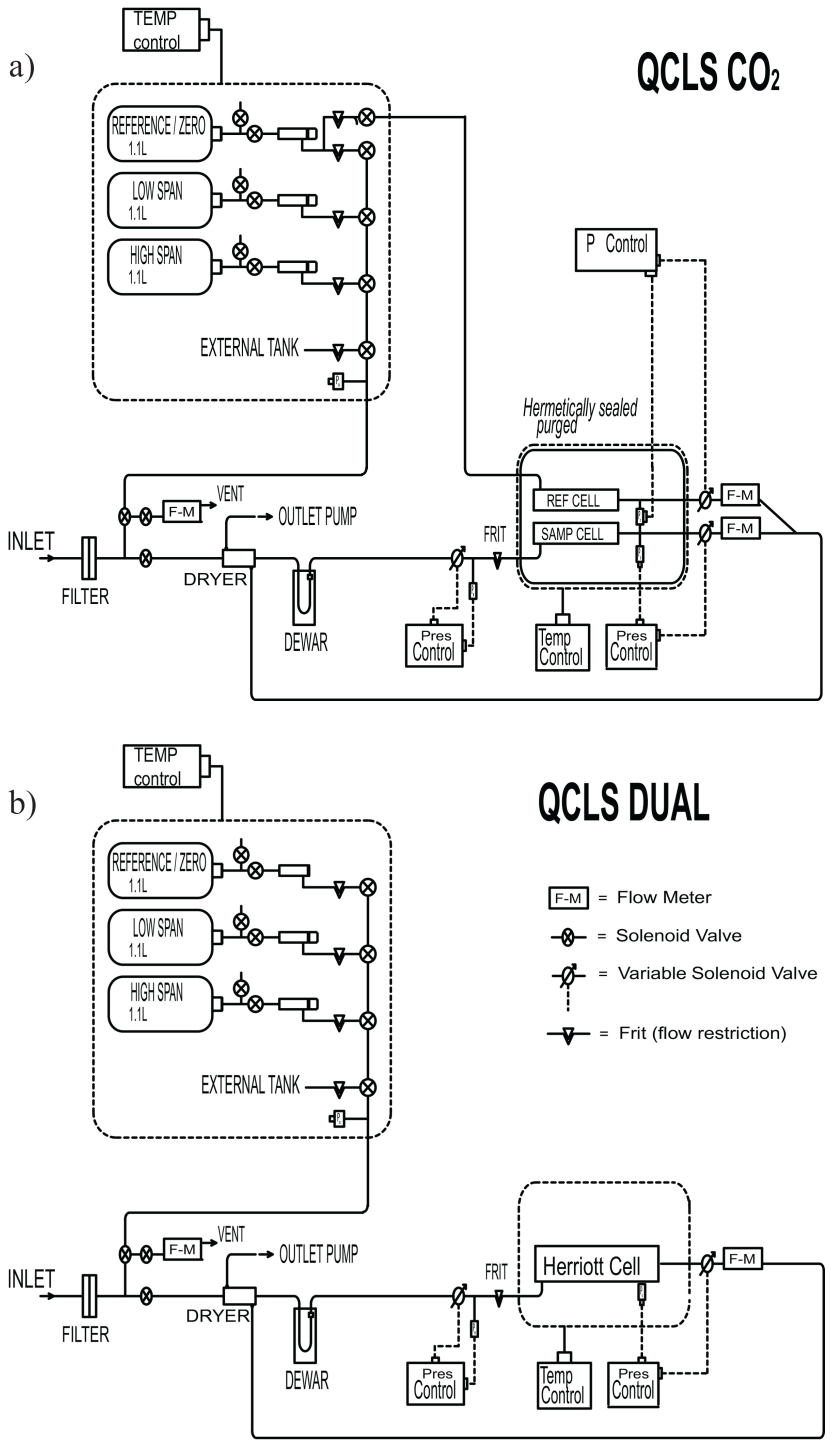

Figure 3. Schematic of the QCLS-CO2 (top) and QCLS-DUAL (bottom) sampling system. The QCLS-CO2 pressure vessel that contains the spectrometer is hermetically sealed and purged with UHP $\mathrm{N}_{2}$ prior to each flight.

The QCLS-CO2 gas deck contains three $1.1 \mathrm{~L}$ carbon-fiber wrapped aluminum compressed air cylinders (SCI ALT-765), and the QCLS-DUAL gas deck has three $2.0 \mathrm{~L}$ cylinders (SCI ALT-764). The QCLS-CO2 gas deck is filled with three whole-air standards containing $\mathrm{CO}_{2}$ dry-air mole fractions in the $\sim 370-410$ ppm range, two of which are used as spans: a low span at $\sim 375 \mathrm{ppm}$, a high span at $\sim 405 \mathrm{ppm}$, and the other as the reference at roughly ambient mole fractions of $\sim 390 \mathrm{ppm}$. The QCLS-DUAL gas deck also contains two spans and a zero, which is ultra-pure whole air. The gas decks are filled using air from size AL (29.5 L) compressed air cylinders ordered from Scott-Marrin (Riverside, CA). The AL cylinders used to fill the QCLS-CO2 gas deck are
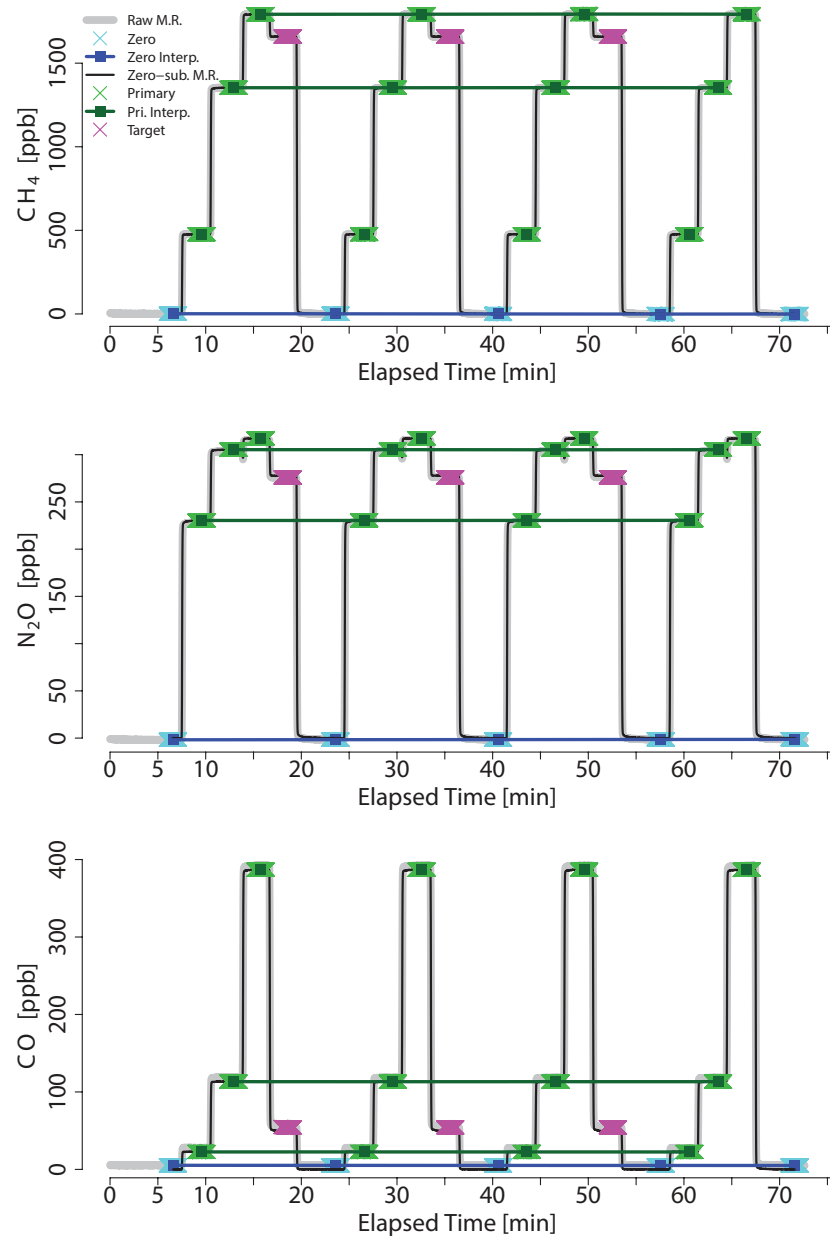

Figure 4. The sampling sequence used to calibrate a secondary cylinder for QCLS-DUAL (Table $2 b$ ) using three primary cylinders (Table 2a). Zero air (light blue) is sampled for $5 \mathrm{~min}$, and the primary cylinders are then each sampled for 3 min (light green) in order of increasing concentration, and then the target secondary cylinder (pink) is sampled for $3 \mathrm{~min}$. We use the last $90 \mathrm{~s}$ of a given 5 min zero-air sample (light blue) to calculate five zero-air values (blue squares). These five values are linearly interpolated (Interp.) to the sampling times, and that time series (blue trace) is then subtracted from the raw mixing ratios (gray trace) to yield the black trace (which appears nearly indistinguishable from the gray trace except in the case of CO). The last $90 \mathrm{~s}$ (light green) of the "zerosubtracted" data (black trace = gray trace - blue trace) are then averaged to generate a value for each of the four primary sampling intervals (dark green squares). For each primary, the primary value at the QCLS sampling times is linearly interpolated to those four values (green lines). The last $90 \mathrm{~s}$ of the target sampling window (pink) are then interpolated (both linearly and quadratically) to the green lines (either the 2 closest for linear interpolation or the closest 3 for quadratic interpolation), which bracket the secondary concentration of interest, as shown in Fig. 5.

calibrated on the historic Harvard Licor-based ground calibration unit discussed in Daube et al. (2002) by comparison to a set of four primary cylinders obtained from NOAA with 

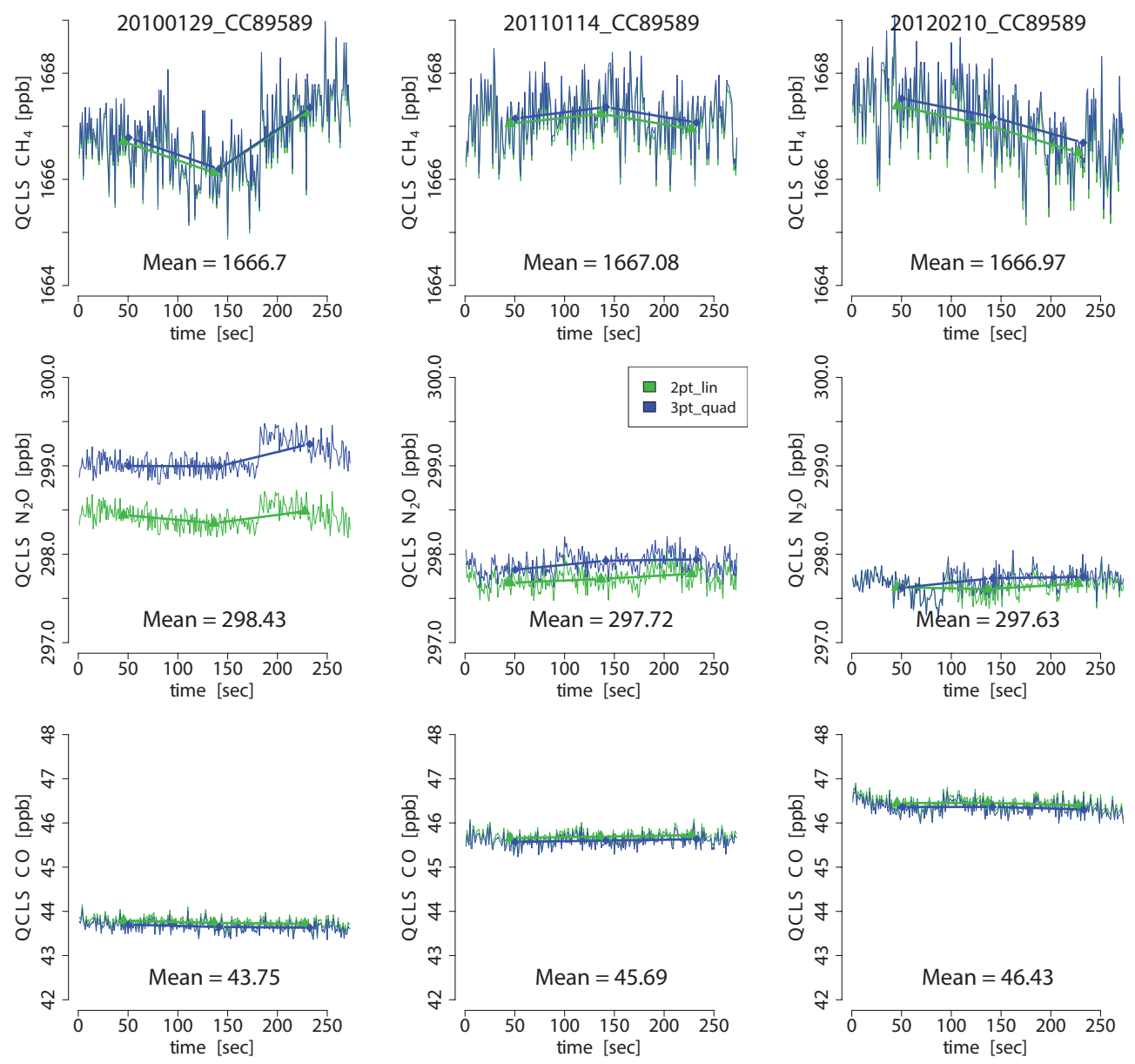

Figure 5. The concatenated target secondary cylinder interpolated values (i.e., the pink points in Fig. 4), which were linearly interpolated to the bracketing primaries (green) or quadratically interpolated to the three closest primaries (blue). The three columns present the calibration of the secondary cylinder QCLS-DUAL gases $\mathrm{CH}_{4}$ (top row), $\mathrm{N}_{2} \mathrm{O}$ (middle row), and $\mathrm{CO}$ (bottom row) for the secondary cylinder CC89589 on 29 January 2010, 14 January 2011, and 10 February 2012, which was used to fill the gas deck for HIPPO III, IV, and V, illustrating the stability of the tank over time. The values printed on the figure represent the mean of the 270 linearly interpolated values. The standard deviations of these values are roughly $0.4,0.05$, and $0.03 \mathrm{ppb}$ for $\mathrm{CH}_{4}, \mathrm{~N}_{2} \mathrm{O}$, and $\mathrm{CO}$, respectively.

$\mathrm{CO}_{2}$ values on the WMO scale (X2007). The AL cylinders used to fill the QCLS-DUAL gas deck are calibrated using the QCLS itself and a set of "primary" size ALM cylinders ( $48.1 \mathrm{~L}$ ) filled at Niwot Ridge and calibrated by NOAA. We refer to the AL cylinders used to fill gas decks as "secondary" calibration cylinders. Secondary cylinders are typically initially pressurized to $\sim 2100 \mathrm{psi}$, and the flight cylinders in the gas decks are filled to as high a pressure as possible, usually $>1800$ psi. Gas-deck cylinders are filled directly from the AL secondary cylinders using $1 / 8^{\prime \prime}$ stainless-steel tubing after three rounds of flushing and purging the regulator and the fill line. The gas-deck cylinders are themselves conditioned by being purged, then filled and flushed twice (to $300 \mathrm{psig}$ then $500 \mathrm{psig}$ ) before being filled to maximum pressure. Gas decks are sampled until the pressure drops to $500 \mathrm{psi}$, well before drifts in concentration become apparent (Daube et al., 2002). Table 2a summarizes the two calibrations of the primary cylinders used in HIPPO and CalNex, and Table $2 b$ summarizes the calibration obtained for the secondary cylinders used to fill the QCLS-DUAL gas deck.

Figure 4 shows the calibration procedure used to calibrate a secondary cylinder for QCLS-DUAL in the lab. We turn on the QCLS and allow it to equilibrate while it is sampling zero-air from an AL cylinder for at least $2 \mathrm{~h}$. Three primary tanks and a secondary "target" tank are plumbed into an external bank of solenoid valves connected to the QCLS-DUAL via an external port on the gas deck. The QCLS is operated in exactly the same mode as during in-flight sample additions of calibrated air, where the calibration solenoid is actuated and excess calibration air (> $200 \mathrm{sccm}$ for QCLS-DUAL) flows out through the QCLS inlet. The primary and secondary tanks are plumbed into the external solenoid bank and the QCLS via $1 / 8^{\prime \prime}$ OD stainless steel tubing. After equilibration, we sample zero-air for $5 \mathrm{~min}$, then sequentially flow air 
Table 2a. Summary of the primary calibration cylinders used during the CalNex and HIPPO campaigns for QCLS-DUAL. The primary cylinders were filled and calibrated at NOAA in 2005, then recalibrated again after CalNex and before HIPPO IV in 2011. The difference between the two calibrations is shown for each tank and each species.

\begin{tabular}{|c|c|c|c|c|c|c|c|c|}
\hline \multirow[b]{2}{*}{ Name } & \multirow[b]{2}{*}{ Cylinder ID } & \multirow[b]{2}{*}{ Cal Date } & \multicolumn{2}{|c|}{$\mathrm{CH}_{4}(\mathrm{ppb})$} & \multicolumn{2}{|c|}{$\mathrm{N}_{2} \mathrm{O}(\mathrm{ppb})$} & \multicolumn{2}{|c|}{$\mathrm{CO}(\mathrm{ppb})$} \\
\hline & & & M.R. & $1 \sigma$ & M.R. & $1 \sigma$ & M.R. & $1 \sigma$ \\
\hline Primary 1 & ND24119 & $7 / 6 / 2005$ & 991.8 & 0.3 & 154.6 & 0.2 & 45.1 & 0.6 \\
\hline \multirow{2}{*}{ Primary 1} & ND24119 & $6 / 30 / 2011$ & 995.2 & 0.3 & 155.0 & 0.2 & 50.4 & 0.2 \\
\hline & & & \multicolumn{2}{|c|}{$\Delta=-3.4$} & \multicolumn{2}{|c|}{$\Delta=-0.4$} & \multicolumn{2}{|c|}{$\Delta=-5.3$} \\
\hline Primary 2 & ND24116 & $7 / 6 / 2005$ & 1361.2 & 0.2 & 326.92 & 0.13 & 102.2 & 0.4 \\
\hline \multirow[t]{2}{*}{ Primary 2} & ND24116 & $8 / 16 / 2011$ & 1363.3 & 0.5 & 326.92 & 0.10 & 103.5 & 0.7 \\
\hline & & & \multicolumn{2}{|c|}{$\Delta=-2.1$} & \multicolumn{2}{|c|}{$\Delta=0$} & \multicolumn{2}{|c|}{$\Delta=-1.3$} \\
\hline Primary 3 & ND24117 & $7 / 11 / 2005$ & 1801.1 & 0.3 & 339.2 & 0.15 & 352.6 & 2 \\
\hline \multirow[t]{2}{*}{ Primary 3} & ND24117 & $6 / 20 / 2011$ & 1801.1 & 0.2 & 339.43 & 0.15 & 352.9 & 0.5 \\
\hline & & & \multicolumn{2}{|c|}{$\Delta=0$} & \multicolumn{2}{|c|}{$\Delta=-0.23$} & \multicolumn{2}{|c|}{$\Delta=-0.3$} \\
\hline Primary 4 & ND24118 & $5 / 5 / 2005$ & 2470.9 & 0.3 & 356.39 & 0.15 & 980.1 & 10 \\
\hline \multirow[t]{2}{*}{ Primary 4} & ND24118 & $8 / 16 / 2011$ & 2466.5 & 1 & 357.03 & 0.16 & 982.4 & 6.7 \\
\hline & & & \multicolumn{2}{|c|}{$\Delta=4.4$} & \multicolumn{2}{|c|}{$\Delta=-0.64$} & \multicolumn{2}{|c|}{$\Delta=-2.3$} \\
\hline Primary 5 & ND29403 & $8 / 30 / 2007$ & 490.5 & 2.4 & 248.12 & 0.10 & 21.5 & 0.1 \\
\hline \multirow[t]{2}{*}{ Primary 5} & ND29403 & $6 / 21 / 2011$ & 486.8 & 0.2 & 247.85 & 0.11 & 22.7 & 0.4 \\
\hline & & & \multicolumn{2}{|c|}{$\Delta=3.7$} & \multicolumn{2}{|c|}{$\Delta=0.27$} & \multicolumn{2}{|c|}{$\Delta=-1.2$} \\
\hline
\end{tabular}

Table 2b. Summary of the secondary calibration cylinders used to fill the gas deck during the CalNex and HIPPO campaigns for QCLSDUAL. Tanks that were used for multiple deployments were recalibrated prior to each use. The naming corresponds to the usage of each cylinder as follows: H1, HIPPO-I; H2, HIPPO-II; H3, HIPPO-III; etc.; CN, CalNex; LS, low span; HS, high span; REF, reference.

\begin{tabular}{lllrrr}
\hline Name & Cylinder ID & Date & $\mathrm{CH}_{4}(\mathrm{ppb})$ & $\mathrm{N}_{2} \mathrm{O}(\mathrm{ppb})$ & $\mathrm{CO}(\mathrm{ppb})$ \\
\hline $\mathrm{H} 1 / \mathrm{H} 2 \mathrm{LS}$ & $\mathrm{CC} 12362$ & $11 / 20 / 2008$ & 1504.94 & 255.11 & 34.76 \\
$\mathrm{H} 1 / \mathrm{H} 2 \mathrm{HS}$ & $\mathrm{CC} 81179$ & $11 / 20 / 2008$ & 1929.76 & 338.52 & 201.69 \\
$\mathrm{H} 1 / \mathrm{H} 2 / \mathrm{CN} \mathrm{LS}$ & $\mathrm{CC} 37815$ & $01 / 29 / 2010$ & 1672.87 & 301.55 & 58.32 \\
$\mathrm{H} 1 / \mathrm{H} 2 / \mathrm{H} 3 \mathrm{HS}$ & $\mathrm{CC} 62384$ & $01 / 29 / 2010$ & 2210.91 & 354.11 & 328.84 \\
$\mathrm{H} 3 / \mathrm{H} 4 / \mathrm{H} 5 \mathrm{LS}$ & $\mathrm{CC} 89589$ & $01 / 29 / 2010$ & 1666.70 & 298.43 & 43.75 \\
$\mathrm{H} 3 / \mathrm{CN}$ HS & $\mathrm{CC} 113530$ & $01 / 29 / 2010$ & 2200.46 & 358.14 & 326.22 \\
$\mathrm{H} 3 \mathrm{REF}$ & $\mathrm{CC} 73108$ & $02 / 01 / 2010$ & 1924.41 & 336.22 & 199.90 \\
$\mathrm{H} 1 / \mathrm{H} 2 / \mathrm{H} 3 \mathrm{HS}$ & $\mathrm{CC} 62384$ & $01 / 12 / 2011$ & 2210.50 & 353.96 & 328.91 \\
$\mathrm{H} 3 / \mathrm{CN} \mathrm{HS}$ & $\mathrm{CC} 113530$ & $01 / 12 / 2011$ & 2201.21 & 358.33 & 327.02 \\
$\mathrm{CN} \mathrm{LS}$ & $\mathrm{CC} 37840$ & $01 / 13 / 2011$ & 1684.78 & 308.85 & 48.17 \\
$\mathrm{CN} \mathrm{HS}$ & $\mathrm{CC} 83782$ & $01 / 13 / 2011$ & 2195.21 & 356.93 & 339.56 \\
$\mathrm{H} 1 / \mathrm{H} 2 / \mathrm{CN} \mathrm{LS}$ & $\mathrm{CC} 37815$ & $01 / 14 / 2011$ & 1672.87 & 301.29 & 58.57 \\
$\mathrm{H} 4 / \mathrm{H} 5 \mathrm{REF}$ & $\mathrm{CC} 56519$ & $01 / 14 / 2011$ & 1803.68 & 331.65 & 146.47 \\
$\mathrm{H} 3 / \mathrm{H} 4 / \mathrm{H} 5 \mathrm{LS}$ & $\mathrm{CC} 89589$ & $01 / 14 / 2011$ & 1667.08 & 297.72 & 45.69 \\
$\mathrm{H} 4 / \mathrm{H} 5 \mathrm{REF}$ & $\mathrm{CC} 56519$ & $02 / 10 / 2012$ & 1803.53 & 331.63 & 140.47 \\
$\mathrm{H} 3 / \mathrm{H} 4 / \mathrm{H} 5 \mathrm{LS}$ & $\mathrm{CC} 89589$ & $02 / 10 / 2012$ & 1666.97 & 297.63 & 46.43 \\
\hline
\end{tabular}

from three primaries in order of lowest to highest concentration for 3 min each. After this sequence, we sample the target secondary tank, also for $3 \mathrm{~min}$. We then repeat this cycle an additional three times, as shown in Fig. 4, not sampling the target secondary on the last iteration. Figure 5 shows the data corresponding to the 270 pink points in Fig. 4, concatenated together for each of the QCLS-DUAL species during three independent sets of calibrations in 2010-2012 for the same tank, CC89589 (Table 2b). We calculate linearly interpolated (using the two closest) and quadratically interpolated (using all three) values that correspond to the mean of the three $90 \mathrm{~s}$ sampling segments. The average of those values is reported as the calibrated secondary values (Table $2 \mathrm{~b}$ ), where values more than $2 \sigma$ from the mean, if they exist, are excluded in the calculation. 
We test for filling errors by filling the gas decks with secondary tanks and then performing a similar calibration of the gas deck itself. For gas-deck calibration, we sample the lowspan and high-span "targets" one after the other and use all four primary cylinders. Because use of the primary cylinders with QCLS required the instrument to be in a laboratory setting, we were able to perform gas-deck calibrations only before or after a given deployment. When the small cylinders in the gas decks reached 500 psi, they were flushed (3 times) and filled with calibration air from AL secondary cylinders. For HIPPO, the refills would take place in Christchurch, NZ, using a different set of secondary cylinders than the secondary cylinders used to fill the gas decks on the first half (southbound) set of the HIPPO flight circuit. We would therefore calibrate the gas deck after filling it but before using it on the southbound flights, and after both filling it and using it on the second half northbound set of the HIPPO flight circuit. Because of these logistics, the calibration values calculated during gas-deck calibrations were only used as a check against filling errors, ensuring that the gas-deck values fell within $3 \sigma$ of the uncertainty attributed to the secondary tank calibration (Fig. 5) from the NOAA primary cylinders. For consistency, and because calibrations of the gas decks themselves required the use of the primary cylinders, the calibration values assigned to the air in the gas decks were always the values from the secondary cylinder calibrations shown in Fig. 5. Figure 5 also shows that, within uncertainty, there is no evidence of drift in the secondary cylinders from 2010 to 2012.

In-flight data are then tied to the NOAA scale by periodic sample replacement with air from the gas decks. The sampling structure is shown in Fig. 6. Within a given $60 \mathrm{~min}$, the calibration sequences is as follows: minutes $7-9,22-24,37-$ 39, 52-54 sampled zero/reference; minutes $9-10$ and 39-40 sampled low span; minutes 10-11 and 40-41 sampled high span; and minutes 41-42 sampled a check span. Because of the different equilibration times for the different species, we changed the order of the LS and HS additions to occur before the zero-air additions (see below). The zero was sampled most frequently at $15 \mathrm{~min}$ intervals to track QCLS drift. The low and high spans were sampled at $30 \mathrm{~min}$ intervals, and the reference span was sampled every hour for $1 \mathrm{~min}$. For a given hour of flight, the effective sampling duty cycle was therefore $\sim 78 \%$ (47 min of sampling per hour). The calibrations for QCLS-DUAL and QCLS-CO2 occur on the same interval. Instead of sampling zero air like QCLS-DUAL, however, the QCLS-CO2 samples the reference gas in both the sample and reference cell in order to obtain a relatively flat spectrum. The zero/reference is sampled for $2 \mathrm{~min}$ for two main reasons: (1) the zero/reference is the most frequently sampled calibration standard and therefore tracks the environmental temperature and pressure variability, which cause drift, and (2) the equilibration of the $\mathrm{N}_{2} \mathrm{O}$ trace is slower than the other species. Because the gas-deck reference/zero-air additions are used to track drift and to interpolate the measurement to standard
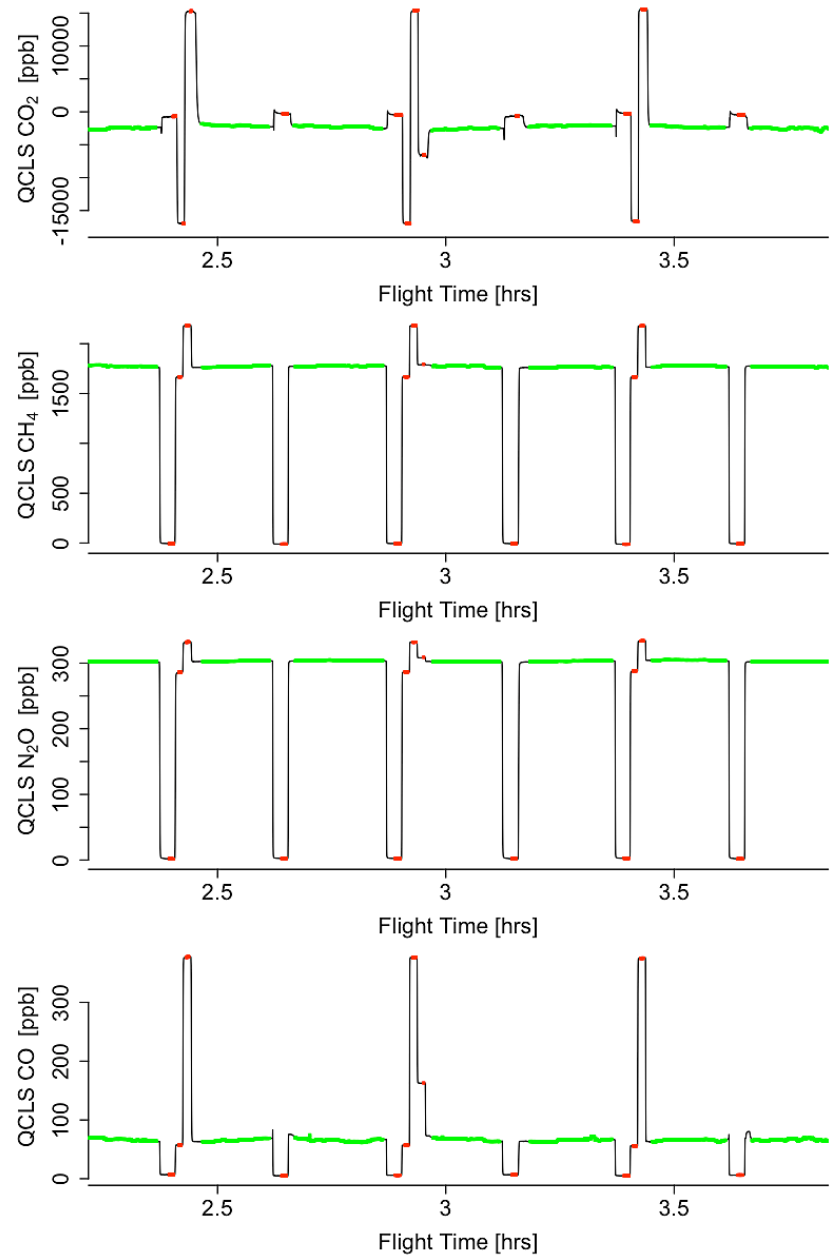

Figure 6. Calibration sequence of in-flight measurements. The reference gas (QCLS-CO2) and zero gas (QCLS-DUAL) are sampled every $15 \mathrm{~min}$, a low span and a high span every $30 \mathrm{~min}$, and a check span every hour. The sample data (green) are then calibrated to the WMO/NOAA scale using the mean values of each group of the calibration spans (red).

values, equilibration of the gas-deck standard additions is essential.

We ran a number of tests to characterize the slow equilibration in $\mathrm{N}_{2} \mathrm{O}$ observed in the zero-air additions. Figure 7 shows a concatenated time series of various sampling intervals in which we repeatedly switched between a zero-air cylinder and a span cylinder for $3 \mathrm{~min}$ intervals. The different colors indicate different combinations of elements upstream of the sampling cell that came into contact with the sample. The tests included instances in which the air went straight from the cylinders to the sampling cell (through a nominal $0.5 \mathrm{~m}$ of Synflex that was unavoidable). Various other upstream elements were added between the cylinder and the sampling cell, including different lengths of Synflex, stainless steel tubing, PFA, and Nafion ${ }^{\mathrm{TM}}$ tubing. Figure 7 shows these data superimposed upon one another (with the zero-air 

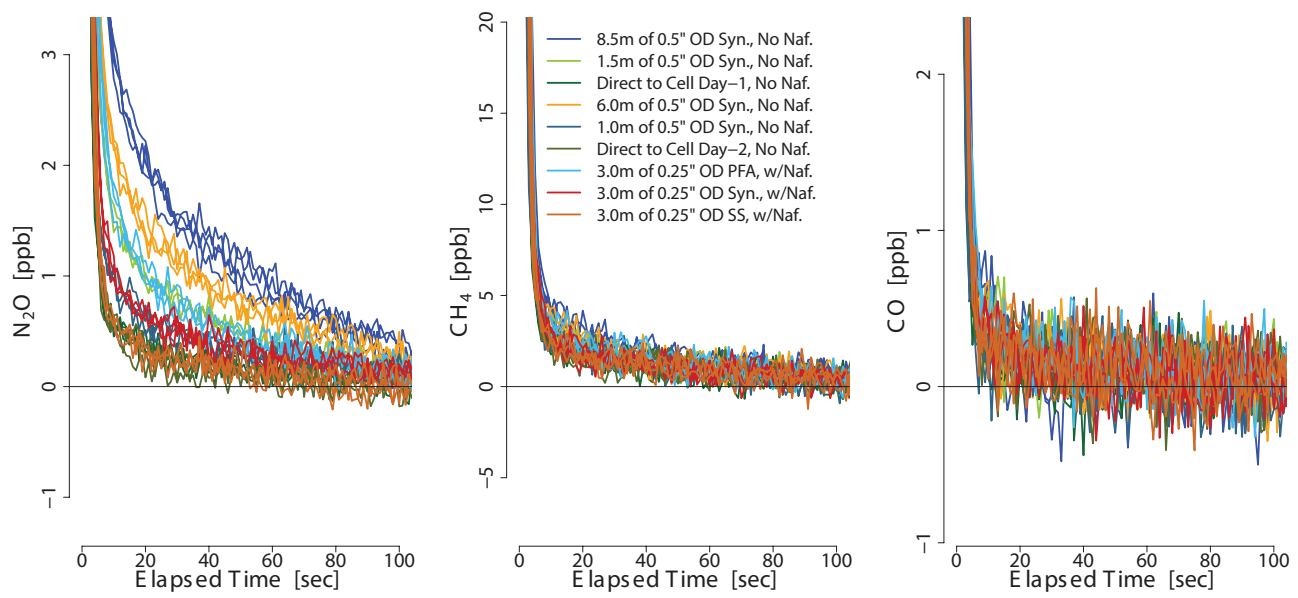

Figure 7. A series of square-wave tests, alternatively sampling from a reference secondary tank with near-ambient concentrations of the QCLS-DUAL species and a zero-air tank every $5 \mathrm{~min}$, superimposed upon one another to illustrate the slow sample equilibration time for $\mathrm{N}_{2} \mathrm{O}$. The $y$ axis range is defined as the difference between the dry-air mole fractions of the secondary tank $\left(\mathrm{N}_{2} \mathrm{O}=319.3 \mathrm{ppb}\right.$, $\mathrm{CH}_{4}=1919.6 \mathrm{ppb}, \mathrm{CO}=223.4 \mathrm{ppb}$ ) and zero (the zero-air mole fractions), each divided by an arbitrary constant (here $\left.=500\right)$ to focus the plot on the transition region. A decrease in the surface area of PFA or Synflex results in a faster equilibration time. $\mathrm{Both}_{\mathrm{CH}}$ and $\mathrm{CO}$ do not exhibit this behavior.

value assigned from the mean value of $145-165 \mathrm{~s}$ of the 180 s sampling window) and the $y$ axis range normalized by the secondary cylinder calibrated value $\left(\mathrm{N}_{2} \mathrm{O}=319.3 \mathrm{ppb}\right.$, $\left.\mathrm{CH}_{4}=1919.6 \mathrm{ppb}, \mathrm{CO}=223.4 \mathrm{ppb}\right)$ and multiplied by an arbitrary constant (here 500) to zoom in on the transition to the zero-air sampling. Both $\mathrm{CH}_{4}$ and $\mathrm{CO}$ are largely unaffected by the different sampling materials, likely because of their lower boiling points $\left(-164{ }^{\circ} \mathrm{C}\right.$ and $-192^{\circ} \mathrm{C}$, respectively) relative to $\mathrm{N}_{2} \mathrm{O}\left(-88^{\circ} \mathrm{C}\right)$. Stainless steel was the only sampling material that was not affected by absorption/desorption for $\mathrm{N}_{2} \mathrm{O}$. This effect scales with the surface area of Synflex or PFA in the sampling system. Using stainless steel is impractical in many instances, so this effect is often unavoidable, but is important to consider in the context of measurement traceability. We reached a compromise by sampling the zero air for 2 min and using a smaller sampling window to calculate the zero-air spectroscopically calibrated mixing ratios of $\mathrm{N}_{2} \mathrm{O}$, as seen in Fig. 6. Following HIPPO II, we changed the order of the zero and span sampling, sampling the LS and HS before sampling the zero air. Figure 6 shows the in flight sampling from HIPPO II before that change was implemented.

Using a reference calibration cylinder (one with nearambient atmospheric concentrations, e.g., CC56519 in Table $2 \mathrm{~b}$ ) instead of a zero to track instrument stability would minimize the effect of this problem. Because this tank is used so frequently to track drift, however, it would have been impractical to use, particularly on HIPPO where opportunities to ship calibration tanks and refill the gas decks are limited. We tested this assumption on one flight during HIPPO V (RF14; 9 September 2011) and showed that using a 1 min equilibration time for a reference tank at ambient concentrations gave nearly equivalent results as using a $2 \mathrm{~min}$ zero-air tank.

It should be noted that the boiling point of $\mathrm{CO}_{2}\left(-57^{\circ} \mathrm{C}\right)$ is even higher than that of $\mathrm{N}_{2} \mathrm{O}$, so this effect is equally important for $\mathrm{CO}_{2}$ and can be observed in Fig. 6. However, it matters to a much smaller extent as the Synflex is always in contact with air that is very close to ambient.

To distinguish sampling intervals from calibration intervals, we use an empirical relationship that is a function of ambient pressure and tubing length. These differ for HIPPO and CalNex because of the hardware configurations, notably the use of the HIMIL on HIPPO. For HIPPO and QCLS-DUAL, we calculate experimental delay times from the HIMIL to the calibration-addition point just downstream of the inlet filter (Fig. 3) as a linear function of ambient pressure in the HIMIL. We also calculate a time delay corresponding to the equilibration time from that point to the measurement cell as a quadratic function of ambient pressure in the HIMIL. These have the following functional form:

$t_{\text {delay }}=1.6201 \cdot P_{\mathrm{amb}}$

$t_{\text {equil }}=0.02763 \cdot P_{\mathrm{amb}}^{2}+0.14993 \cdot P_{\mathrm{amb}}+3.75488$,

where time and pressure have units of $\mathrm{s}$ and mbar. The dynamic range of ambient pressure is much smaller in CalNex and does not include a HIMIL, which affects the pressure at the inlet, so the equilibration time for CalNex is treated as a constant value derived from plume comparisons between QCLS and a fast-response black-carbon measurement (Schwarz et al., 2010) that was available for both HIPPO 

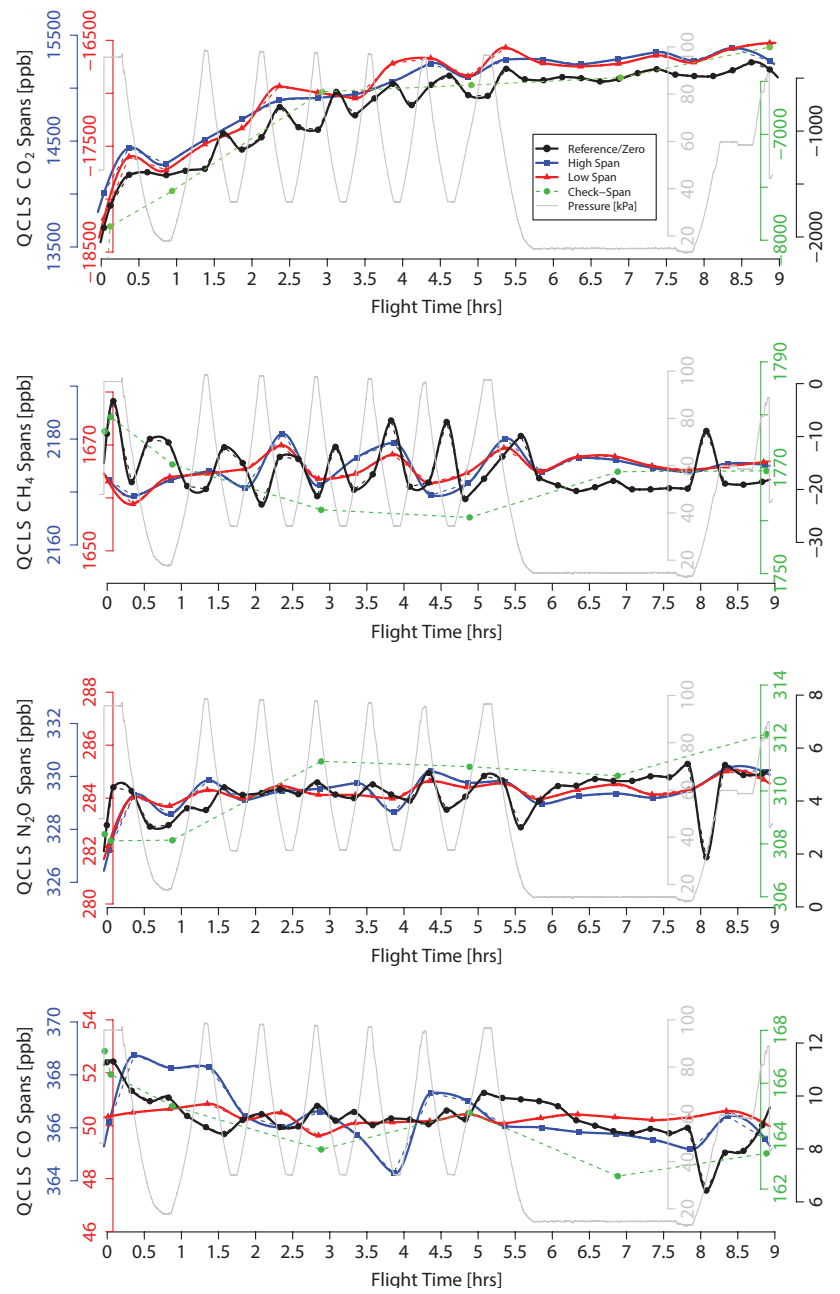

Figure 8. The gas-deck in-flight calibration addition stability over the course of RF09 on HIPPO V. Each point represents the average of the group of red points in Fig. 6, and the axes for each QCLS species are equivalent in range. The lines represent the Akima spline interpolations to the different spans (red - low span, blue - high span, black - zero) and are used to relate the spectroscopically calibrated mixing ratios to the NOAA scale. QCLS-CO2 and QCLSDUAL use different interpolation techniques as discussed in the text. The HIMIL inlet pressure is also shown in gray.

and CalNex. Equations for QCLS-CO2 have different coefficients but the same form. The equations were calculated empirically during several test flights on each campaign and then held constant throughout each campaign.

The HIMIL port, designed to slow air flow, complicated the instrument equilibration time but dampened the input pressure variability of the sample. For CalNex, however, the variability in the sample pressure was occasionally not adequately controlled by the pressure control elements. Certain fluctuations in pressure were able to propagate to the QCLS-DUAL sample cell and affect the measurements. The effect of this cell "ringing" was most apparent in the $\mathrm{N}_{2} \mathrm{O}$ measurement, which occasionally showed high-frequency $(1 \mathrm{~Hz})$ positive and negative excursions of $>1-2 \mathrm{ppb}$ for $\mathrm{N}_{2} \mathrm{O}$, a trace that should only see negative excursions in stratospheric air. We apply a filter that removed measurements in which the $1 \mathrm{~Hz}$ rate change of pressure is greater than 3 standard deviations of the mean $\left(\sigma=0.16 \mathrm{hPa} \mathrm{s}^{-1}\right)$. This resulted in an effective duty cycle that was $3 \%$ lower than without the pressure filter, but removed spurious spikes in the data.

Calibration time intervals were determined using these functions and the solenoid valve actuation time, and a mean mixing ratio for each sample addition was calculated in a given window. The zero-air values measured every $15 \mathrm{~min}$ were then fit using a penalized Akima spline interpolation technique (Akima, 1970) to evaluate the drift of the instrumentation. Other filters, such as loess, splines, and interpolators, occasionally cause severe curvature in the interpolation, particularly near the beginning of flight where sensors may not be fully equilibrated. This zero-air Akima spline is evaluated at all the $1 \mathrm{~Hz}$ sampling times and subtracted from the entire data set. Using the zero-air Akima-spline-subtracted data for the QCLS-DUAL species (for example, $\mathrm{CH}_{4, \text { Zraw }}$ ), the mean values of each low-span and high-span window are interpolated using the same Akima spline to the measurement times. $\mathrm{CH}_{4 \text {, Zraw }}$ is then linearly interpolated to the low-span Akima spline and high-span Akima spline $\left(\mathrm{CH}_{4, \mathrm{Z} \_\mathrm{ALS}}\right.$ and $\mathrm{CH}_{4, \mathrm{Z} \_\mathrm{AHS}}$, respectively) according to

$$
\begin{aligned}
\mathrm{CH}_{4, \mathrm{cal}} & =\left(\frac{\mathrm{CH}_{4, \mathrm{Z} \text { raw }}-\mathrm{CH}_{4, \mathrm{Z} \_\mathrm{ALS}}}{\mathrm{CH}_{4, \mathrm{Z} \_\mathrm{AHS}}-\mathrm{CH}_{4, \mathrm{Z} \_\mathrm{ALS}}}\right) \\
& \cdot\left(\mathrm{CH}_{4, \mathrm{HS} \mathrm{VAL}_{\mathrm{VAL}}-\mathrm{CH}_{4, \mathrm{LS}} \mathrm{VAL}}\right)+\mathrm{CH}_{4, \mathrm{LS} \mathrm{VAL}_{\mathrm{VAL}}},
\end{aligned}
$$

where $\mathrm{CH}_{4, \mathrm{LS}_{\mathrm{VAL}}}$ and $\mathrm{CH}_{4, \mathrm{HS}} \mathrm{VAL}_{\mathrm{V}}$ are the two constant values of the low-span and high-span secondary AL calibration cylinders used to fill the gas deck (Table 2b). The equations for $\mathrm{N}_{2} \mathrm{O}$ and $\mathrm{CO}$ are equivalent and generate the calibrated sample dry-air mole fractions $\left(\mathrm{CH}_{4, \text { cal }}\right.$ in Eq. 3). Figure 8 shows the different Akima splines for an arbitrary flight during HIPPO V, along with the ambient pressure. The axes are all scaled such that the different tracers - zero air, low span, high span, and reference air - from the gas decks have equivalent ordinate ranges. The $\mathrm{CO}_{2}$ trace in Fig. 8 is in units of $\mathrm{ppb}$ relative to the reference, meaning that a value of -17500 corresponds to the low span that is $17.5 \mathrm{ppm}$ lower than the near-ambient reference. Figure 8 is a standard output product of the batch processing and is purposely scaled to emphasize the fluctuations of calibration standards over the course of a given flight. Because of the linear interpolation between the zero-subtracted low span and high span, the relative fluctuation of those two standards has the largest effect on the effective calibrated measurements.

The $\mathrm{CO}_{2}$ calibration additions shown in Fig. 8 are treated in a slightly different fashion than the QCLS-DUAL species. Because QCLS-CO2 is a differential measurement and the range of observations is the largest of any species (in terms of 


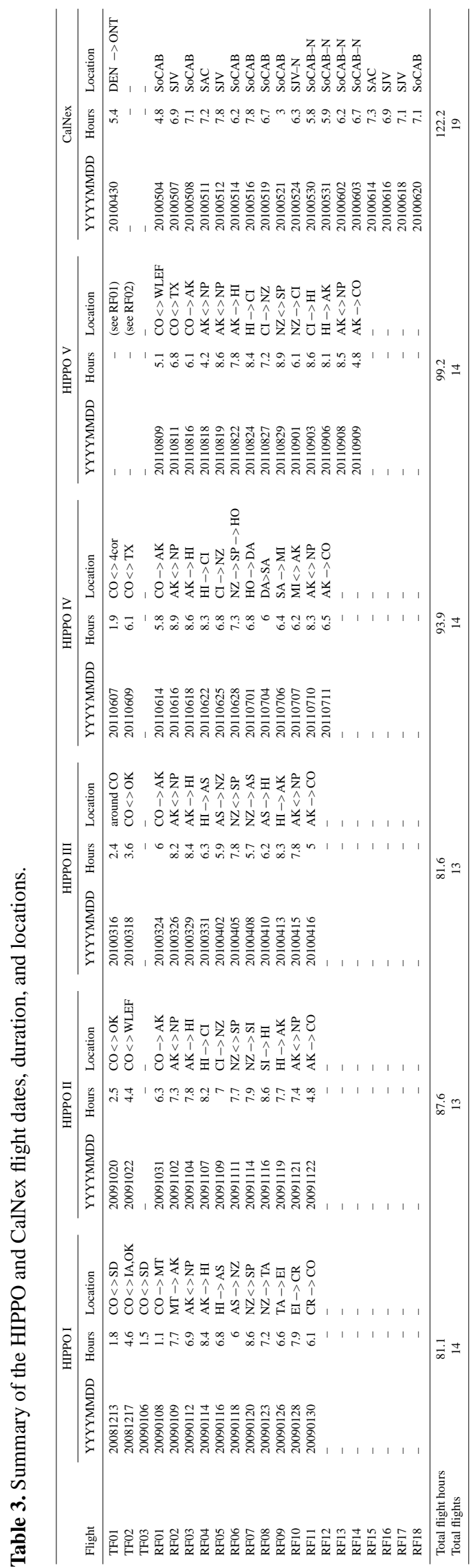


Table 4. Biases between QCLS and NOAA flask measurements at the reported mean concentrations of each species for the five HIPPO campaigns.

\begin{tabular}{lrrrrrrrr}
\hline & $\begin{array}{r}\mathrm{CO}_{2} \text { bias } \\
(\mathrm{ppm})\end{array}$ & $\begin{array}{r}\mathrm{CO}_{2} \\
(\mathrm{ppm})\end{array}$ & $\begin{array}{r}\mathrm{CH}_{4} \text { bias } \\
(\mathrm{ppb})\end{array}$ & $\begin{array}{r}\mathrm{CH}_{4} \\
(\mathrm{ppb})\end{array}$ & $\begin{array}{r}\mathrm{N}_{2} \mathrm{O} \text { bias } \\
(\mathrm{ppb})\end{array}$ & $\begin{array}{r}\mathrm{N}_{2} \mathrm{O} \\
(\mathrm{ppb})\end{array}$ & $\begin{array}{r}\mathrm{CO} \text { bias } \\
(\mathrm{ppb})\end{array}$ & $\begin{array}{r}\mathrm{CO} \\
(\mathrm{ppb})\end{array}$ \\
\hline HIPPO I & 0.14 & 385.9 & 1.2 & 1788.1 & 0.61 & 321.0 & -3.71 & 77.3 \\
HIPPO II & -0.06 & 386.7 & 0.75 & 1801.2 & 1.18 & 320.9 & -1.52 & 84.0 \\
HIPPO III & -0.09 & 389.9 & 0.44 & 1795.0 & 1.15 & 320.0 & -1.59 & 95.3 \\
HIPPO IV & -0.25 & 390.6 & 1.04 & 1800.0 & 1.23 & 322.8 & -1.14 & 72.2 \\
HIPPO V & -0.3 & 387.5 & 0.79 & 1813.7 & 1.18 & 322.4 & -1.72 & 74.5 \\
\hline Mean & -0.11 & 0.85 & & 1.07 & & -1.94 \\
\hline
\end{tabular}

concentration changes measured over the course of a flight), the $\mathrm{CO}_{2}$ interpolation is not calculated linearly. Instead, we take the median of the low-span, reference, and high-span values calculated over the course of any particular flight and fit a quadratic function to those median values for that flight. The reference-subtracted measurements are then quadratically interpolated using this fixed function. We experimented with different methods to calibrate the $\mathrm{CO}_{2}$ measurements and found that using a method similar to QCLS-DUAL resulted in spurious wave generation in the measurements that was not physical. Because the reference/zero calibration is sampled at 2 times the frequency of the spans, the reference trace is able to best compensate for the measurement drift. Physically, we expect that the response of QCLS-CO2 over the range of concentrations sampled should not change dramatically, and this is confirmed in the flight-to-flight variability of the quadratic interpolation function (see below). For this reason, we fix the quadratic function and make it follow the more frequent reference calibration trace.

Figure 9 shows the variability of the quadratic function for QCLS-CO2 (during CalNex) and the linearity of QCLSDUAL (in lab using data from a secondary tank calibration). The four sets of panels show the 1:1 plot of the raw spectroscopically calibrated QCLS mixing ratios versus the NOAAcalibrated primary cylinder values. The linear fits to QCLSDUAL are calculated using a type II regression with prescribed errors in the abscissa and ordinate (York, 2004). For the $x$ axis, the uncertainties are prescribed by the NOAA calibrations; for the $y$ axis, errors are given by the standard deviation of the mean spectroscopically calibrated QCLS measurements. The bottom panel shows the residual values for the different tanks. For $\mathrm{CO}_{2}$, the fit is not linear, as described above, and the residuals shown are flight-to-flight differences in the quadratic fit function over the course of the CalNex mission, which showed greater variance in the quadratic fit coefficients compared to HIPPO. The residual values shown for $\mathrm{CO}_{2}$ correspond to the standard deviation of the quadratic fit function over the mission, and can be considered an estimate of the sensor accuracy as a function of concentration. To put these estimates of errors in context, the histogram distributions of the HIPPO and CalNex $\mathrm{CO}_{2}$ measurements are shown along with their 10-90\% quantile ranges (solid blue and red lines) to show that this is a very minor error effect for the majority of the measurements.

The accuracy of the QCLS-CO2 measurements is determined by secondary cylinders calibrated against NOAA standards using the Harvard ground support equipment (GSE), described in detail in Daube et al. (2002). The GSE is a Licor model 6251 non-dispersive infrared (NDIR) analyzer, which measures molecular absorption of $\mathrm{CO}_{2}$ in a sample stream relative to a reference stream of air. Because it is a nondispersive analyzer, the measurement is sensitive to different parts of the molecular absorption band of $\mathrm{CO}_{2}$. Tohjima et al. (2009) characterized the sensitivity of three Licors (two 6252 's and one 6262) to each of the isotopologues of $\mathrm{CO}_{2}$. They use a relative molar response (RMR) value for each isotopologue to calculate the effective change in concentration determined for each isotopologue (see their Table 4). Given a hypothetical $\mathrm{CO}_{2}$ mixing ratio of $400 \mathrm{ppm}$, the isotopic abundances in HITRAN (Rothman et al., 2009) can be used to approximate the individual mixing ratios of the three dominant isotopologues $-{ }^{16} \mathrm{O}^{12} \mathrm{C}^{16} \mathrm{O},{ }^{16} \mathrm{O}^{13} \mathrm{C}^{16} \mathrm{O}$, and ${ }^{16} \mathrm{O}^{12} \mathrm{C}^{18} \mathrm{O}$ - as $393.68160,4.42296$ and $1.57883 \mathrm{ppm}$, respectively. The sum of these three concentrations is less than 400 (399.68339) as other minor isotopes contribute to the total concentration. Atmospheric $\mathrm{CO}_{2}$ has an approximate isotopic composition of $\delta^{13} \mathrm{C}=-10 \%$ and $\delta^{18} \mathrm{O}=40 \%$, where these quantities are calculated according to

$\delta^{13} \mathrm{C}_{\mathrm{CO}_{2}}=\left[\frac{\mathrm{R} 13_{\mathrm{sam}}}{\mathrm{R} 13_{\mathrm{vpdb}}}-1\right] \cdot 1000$,

$\delta^{13} \mathrm{O}_{\mathrm{CO}_{2}}=\left[\frac{\mathrm{R} 18_{\text {sam }}}{\mathrm{R} 18_{\mathrm{vsmow}}}-1\right] \cdot 1000$,

where $\mathrm{R} 13$ represents the ratio of ${ }^{13} \mathrm{C}$ to ${ }^{12} \mathrm{C}$ in a sample of $\mathrm{CO}_{2}$ or in the standard Vienna Pee Dee Belemnite $(\mathrm{vpdb}=0.011180)$, and $\mathrm{R} 18$ represents the ratio of ${ }^{18} \mathrm{O}$ to ${ }^{16} \mathrm{O}$ in $\mathrm{CO}_{2}$ or in standard mean ocean water $(\mathrm{smow}=0.0020052)$. Using these equations, we can calculate atmospheric values for R13 and R18 of 0.0110682 and 0.002085408 , respectively. The abundance of the dominant 

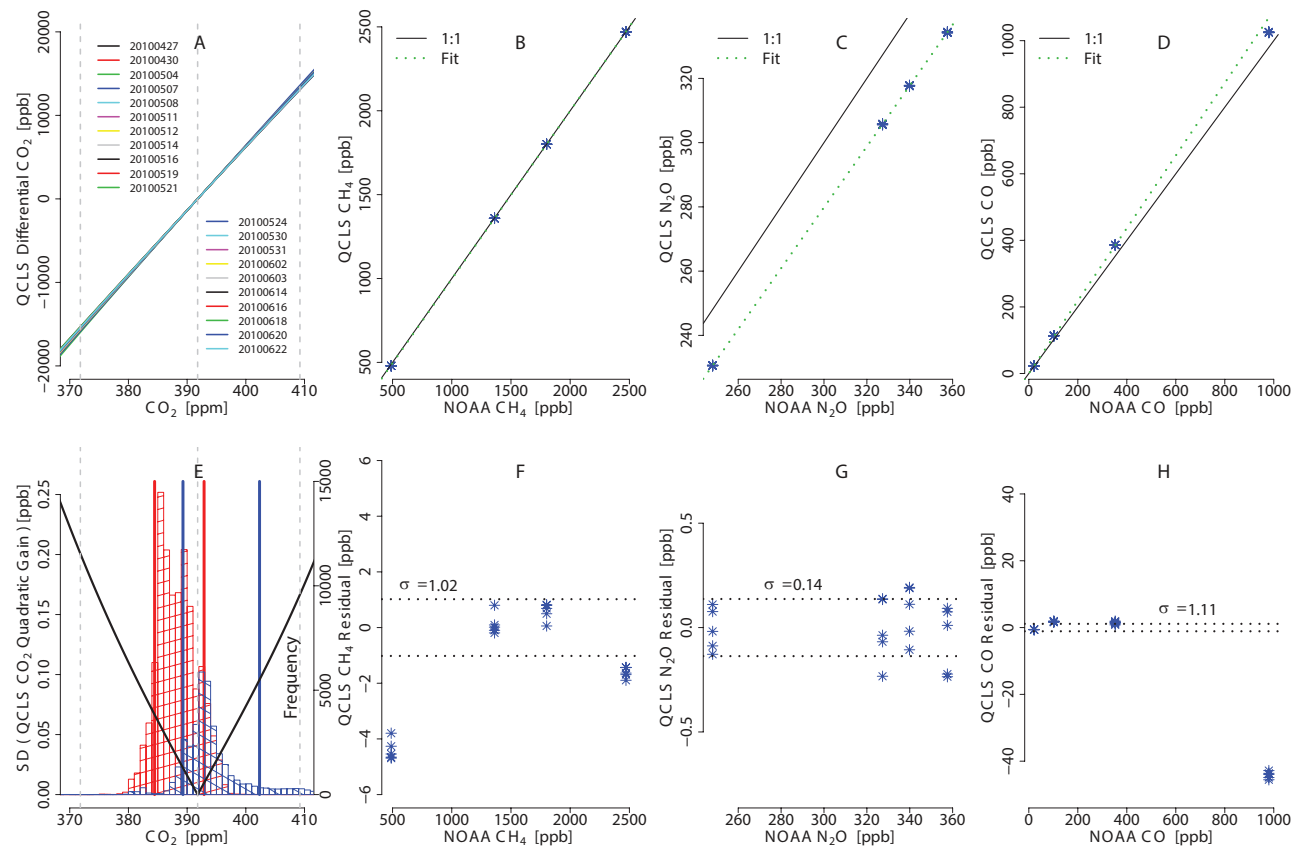

Figure 9. An estimate of the calibration linearity (A-D) and uncertainty (E-H) for the four QCLS species. For QCLS-CO2 (A), the quadratic interpolation function for each research flight in CalNex (which was more variable than in HIPPO; colored dates range from 27 April 2010 to 22 June 2010) is shown. The standard deviation across the 21 flights as a function of calibrated mixing ratio reaches a minimum at the value of the reference gas-deck calibration cylinder as shown in the bottom panel (E) where the black lines converge at $\sim 392$ ppm. The histograms (E) of the CalNex (blue) and HIPPO (red) are shown, and the 10\% and $90 \%$ quantiles are plotted as vertical lines for each, indicating that the variability in the quadratic interpolation function typically contributes no more than 0.1 ppm (i.e., black line intersects blue and red lines within 0.1 ppm). For QCLS-DUAL (B, C, D), the 1:1 correspondence of the spectroscopically calibrated QCLS mixing ratio is plotted against four known primary cylinders, and regressions are calculated using the error uncertainties from the primary cylinders shown in Table 2a. Panels $(\mathbf{F}),(\mathbf{G})$, and $\mathbf{( H )}$ show the standard deviation of the residual uncertainty, where we exclude the very low $\mathrm{CH}_{4}$ primary ( $\sim 500 \mathrm{ppb}$, panels $\mathbf{B}$ and $\mathbf{F})$ and the very high $\mathrm{CO}(\sim 1000 \mathrm{ppb}$, panels $\mathbf{D}$ and $\mathbf{H})$ from the uncertainty estimate.

isotopologue $\left({ }^{12} \mathrm{C}^{16} \mathrm{O}^{16} \mathrm{O}\right)$ must therefore be 1 minus the R13 and twice the R18 abundances, or 0.984761 , which corresponds to a concentration of 393.592606. Because QCLS$\mathrm{CO} 2$ only scans across one absorption line for the dominant isotopologue (mass 44), calibration additions using cylinders with non-atmospheric isotopic composition can therefore result in biases in the measurements. A hypothetical tank that has a total $\mathrm{CO}_{2}$ concentration of $400 \mathrm{ppm}$ and isotopic composition of $\delta^{13} \mathrm{C}=-35 \%$ o and $\delta^{18} \mathrm{O}=10 \%$ o (typical of a Scott Marrin cylinder) will have dominant isotopologue ${ }^{16} \mathrm{O}^{12} \mathrm{C}^{16} \mathrm{O},{ }^{16} \mathrm{O}^{13} \mathrm{C}^{16} \mathrm{O}$, and ${ }^{16} \mathrm{O}^{12} \mathrm{C}^{18} \mathrm{O}$ concentrations of $393.752405,4.312064$ and $1.618919 \mathrm{ppm}$, the sum of which is still 399.68339. But the concentration of the ${ }^{12} \mathrm{C}^{16} \mathrm{O}_{2}$ isotopologue is higher by $0.1598 \mathrm{ppm}$ compared to the concentration with near-atmospheric isotopic composition. This must be accounted for in relating calibration cylinder values to sample concentrations.

The mean RMR corrections for the three dominant isotopologues from the two Licor-6252's are (1) the mean of 1.0073 and $1.0040,(2)$ the mean of 0.21 and 0.45 , and (3) the mean of 1.26 and 1.43 , which are multiplied by the difference in isotopologue concentrations between the $400 \mathrm{ppm}$ cylinder and the $400 \mathrm{ppm}$ atmospheric sample. When summed, the mean value is $-0.059 \mathrm{ppm}$ with a range over the two instruments of -0.041 to $-0.077 \mathrm{ppm}$. Chen et al. (2010) calculated a similar value using specific isotopic composition of the tanks of $-0.09 \mathrm{ppm}$.

To account for the combined effect on the QCLS-CO2 calibration, the $-0.059 \mathrm{ppm}$ and the 0.1598 values must be added to the retrieved sample mixing ratio. The $-0.059 \mathrm{ppm}$ puts the calibration cylinder values calculated using the GSE onto the same isotopic scale as the NOAA primaries (i.e., atmospheric isotopic composition). The 0.1598 value accounts for the fact that QCLS-CO2 derives a total mixing ratio using the absorption spectrum of the dominant ${ }^{12} \mathrm{C}^{16} \mathrm{O}_{2}$ isotopologue and the HITRAN abundance, which differs from the atmospheric abundance as shown above. These effects partially offset, but result in a $\sim 0.1 \mathrm{ppm}$ bias term, which is important considering that atmospheric concentration gradients are often not much larger than this. The particular isotopic values of the calibration cylinders (Table $2 b$ ) were measured by the Stable Isotope Ratio Facility for Environmental Research (SIRFER) and were used to calculate the exact corrections for the tanks. The NOAA primary tanks had 

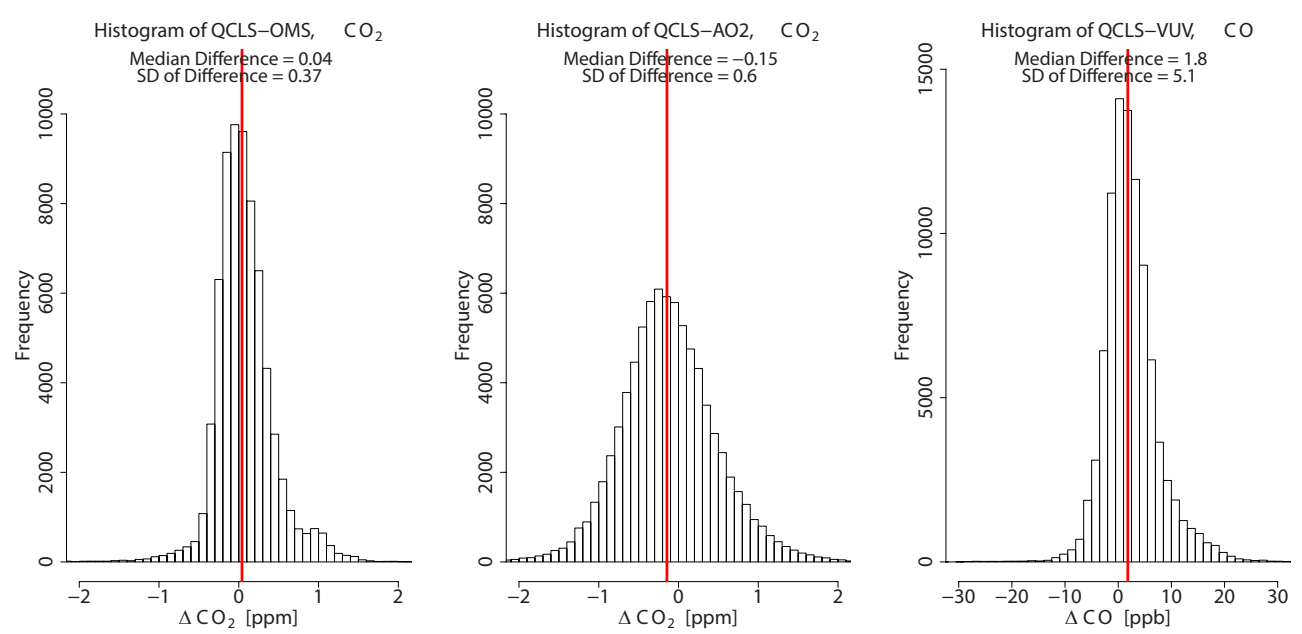

Figure 10. The $1 \mathrm{~Hz}$ HIPPO I-V data comparison for QCLS-CO2 with OMS (left) and AO2 (middle) as well as the QCLS-DUAL CO comparison with the RAF VUV-CO.
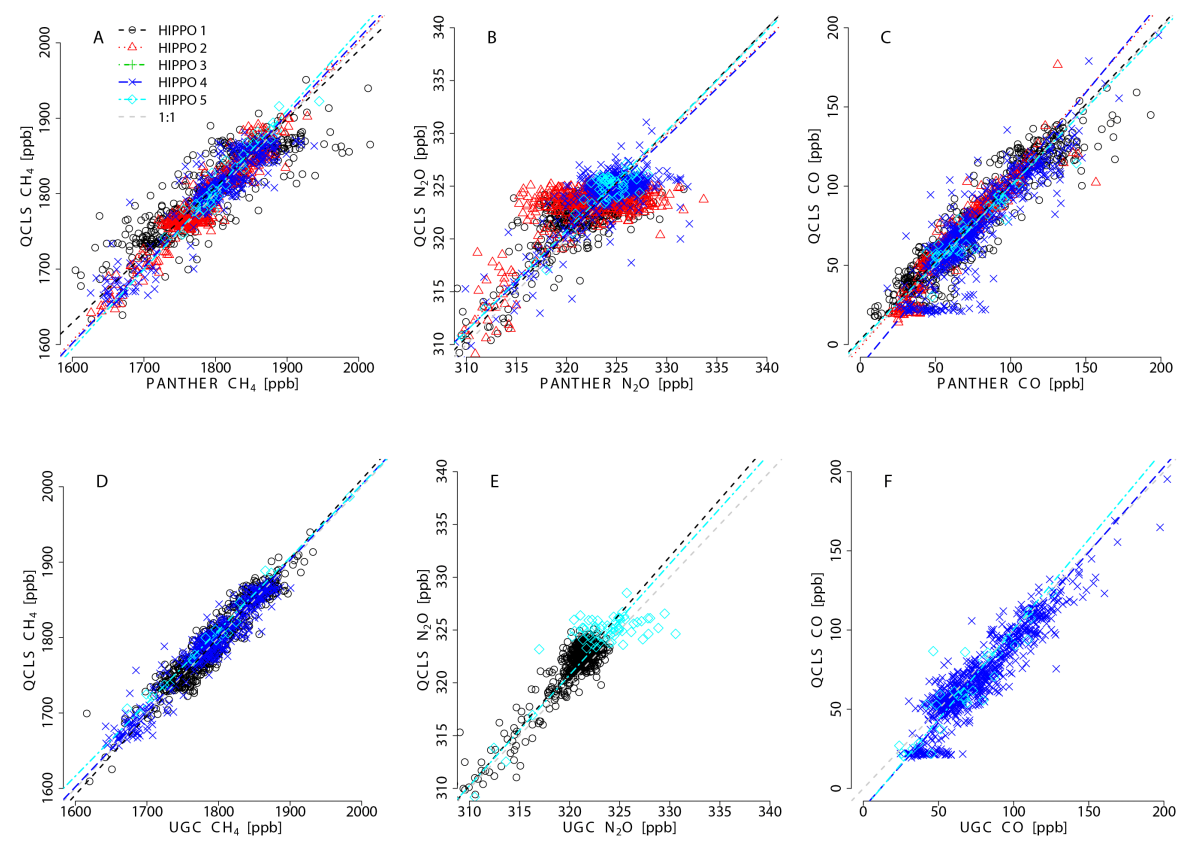

Figure 11. QCLS-DUAL comparisons to the onboard gas chromatographs PANTHER $(\mathbf{A}, \mathbf{B}, \mathbf{C})$ and UCATS $(\mathbf{D}, \mathbf{E}, \mathbf{F})$ for CH $4(\mathbf{A}, \mathbf{D})$, $\mathrm{N}_{2} \mathrm{O}(\mathbf{B}, \mathbf{E})$, and $\mathrm{CO}(\mathbf{C}, \mathbf{F})$. The UCATS instrument had issues with the chromatography during HIPPO II and is not shown. The HIPPO IV measurements of $\mathrm{N}_{2} \mathrm{O}$ from UCATS were also excluded because of non-linear instrument response during several flights.

near-atmospheric ${ }^{13} \mathrm{C}$ isotopic composition of around -10 to $-15 \%$ o, Scott Specialty tanks usually fell in the -45 to $-50 \%$ range, and Scott-Marrin usually fell in the -30 to $-40 \%$ range.

The error for $\mathrm{CH}_{4}$ due to differing isotopic composition between the atmosphere $\left({ }^{13} \mathrm{C} \approx-47 \%\right.$ ) and calibration cylinders $\left({ }^{13} \mathrm{C} \approx-30 \%\right.$ o was calculated to be a $\sim 0.3$ ppb effect, smaller than the $1 \mathrm{~Hz}$ precision. The effects for $\mathrm{N}_{2} \mathrm{O}$ and $\mathrm{CO}$ were proportionally smaller, and these effects are therefore ignored for QCLS-DUAL.

\section{Missions and other instrumentation}

The QCLS was operated in the same configuration on all CalNex and HIPPO flights (Table 3) with only minor changes due to the aircraft-specific issues already discussed. We now present comparisons with other coincident instruments, synchronized in time using the STRATUM-1 aircraft data system.

For HIPPO, two additional fast-response $(>1 \mathrm{~Hz}) \mathrm{CO}_{2}$ sensors were available for comparison: the historic 

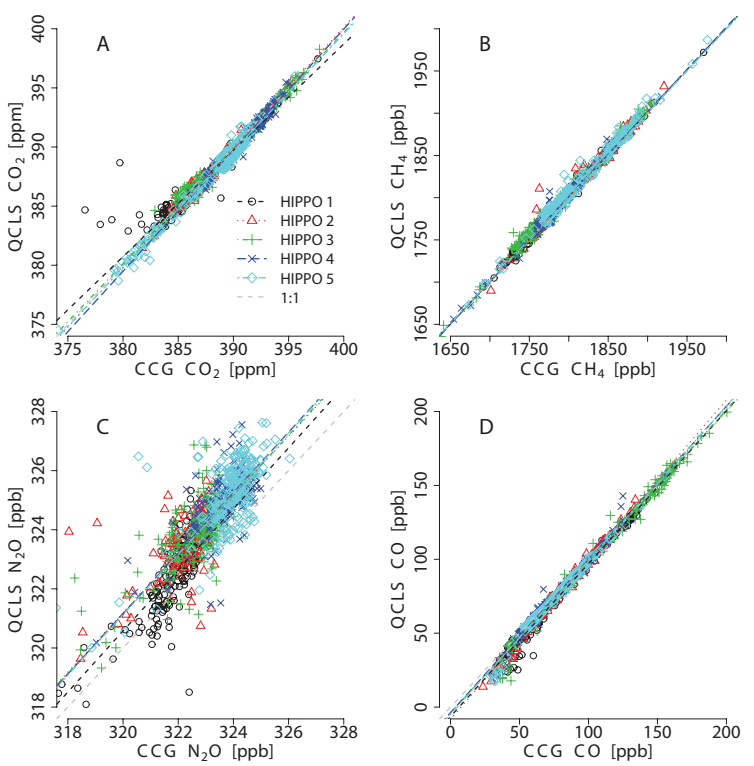

Figure 12. QCLS comparisons to NOAA flask data during HIPPO $\mathrm{I}-\mathrm{V}$ for $\mathrm{CO}_{2}(\mathbf{A}), \mathrm{CH}_{4}$ (B), $\mathrm{N}_{2} \mathrm{O}(\mathbf{C})$, and $\mathrm{CO}$ (D). With the exception of $\mathrm{N}_{2} \mathrm{O}$, which has a much tighter correlation with the flask measurements, the axes are all scaled to the same ranges as Fig. 11. The biases for each fit are reported in Table 4. The type II regressions (York, 2004) in these figures use uncertainty values of 200 , 2, 0.2, and $1 \mathrm{ppb}$ for the QCLS measurements of $\mathrm{CO}_{2}, \mathrm{CH}_{4}, \mathrm{~N}_{2} \mathrm{O}$, and $\mathrm{CO}$, respectively, corresponding to the calibration uncertainties shown in Table 2a, and half of those values for the NOAA CCG flask values (Zhao and Tans, 2006; Dlugokencky et al., 2005; Hall et al., 2007; Novelli et al., 1994).

Observations of the Middle Stratosphere (OMS) sensor (Daube et al., 2002) and the NCAR Airborne Oxygen Instrument (AO2), which includes a single-cell Licor-820 sensor. Figure 10 shows the $1 \mathrm{~Hz}$ measurement difference distribution for QCLS against OMS and AO2 for all HIPPO flights. QCLS-CO2 and OMS agree to better than $0.05 \mathrm{ppm}$, with a standard deviation of the difference of 0.37 , owing in part to the slower cell response time of OMS. Assuming the sensors have no covariance, the $1 \mathrm{~Hz}$ OMS precision of $0.1 \mathrm{ppm}$ and the $1 \mathrm{~Hz}$ QCLS precision of $0.02 \mathrm{ppm}$ would sum in quadrature for an expected precision of $0.1 \mathrm{ppm}$. The actual distribution is $0.37 \mathrm{ppm}$, roughly a factor of 4 higher. The $\mathrm{AO} 2$ instrument has a $1 \sigma, 1 \mathrm{~s}$ precision of $\sim 0.6 \mathrm{ppm}$. QCLS-CO2 and $\mathrm{AO} 2$ agree to within $0.15 \mathrm{ppm}$ and have an even larger variance on the distribution of the measurement differences. It is important to note that many unresolved biases spanning $1 \mathrm{~h}$ or an entire flight exist among the $\mathrm{CO}_{2}$ sensors on HIPPO and tend to average out as presented in Fig. 10. The Research Aviation Facility (RAF) vacuum ultraviolet (VUV) CO sensor is the only other fast-response instrument measuring one of the QCLS species (Gerbig et al., 1999). That comparison, also shown in Fig. 10, shows a bias of 1.8 ppb over the HIPPO mission.
Table 5. Biases between QCLS and MEDUSA flask measurements at the reported mean concentrations of $\mathrm{CO}_{2}$ for the five HIPPO campaigns.

\begin{tabular}{lrr}
\hline & $\begin{array}{r}\mathrm{CO}_{2} \text { bias } \\
(\mathrm{ppm})\end{array}$ & $\begin{array}{r}\mathrm{CO}_{2} \\
(\mathrm{ppm})\end{array}$ \\
\hline HIPPO I & -0.28 & 386.16 \\
HIPPO II & 0.03 & 386.54 \\
HIPPO III & 0.03 & 389.48 \\
HIPPO IV & -0.14 & 390.30 \\
HIPPO V & -0.18 & 387.70 \\
\hline Mean & -0.11 & \\
\hline
\end{tabular}

Two onboard gas chromatographs - the Unmanned Aircraft Systems (UAS) Chromatograph for Atmospheric Trace Species (UCATS, Moore et al., 2003; Fahey et al., 2006; Wofsy et al., 2011) and the PAN and other Trace Hydrohalocarbon ExpeRiment (PANTHER; Elkins et al., 2002; Wofsy et al., 2011) - measured a variety of chemical species including $\mathrm{CH}_{4}, \mathrm{~N}_{2} \mathrm{O}$, and $\mathrm{CO}$. Figure 11 shows the one-to-one comparison of the QCLS to PANTHER (top) and UCATS (bottom) after applying the averaging kernel of each gas chromatograph (GC) to the $1 \mathrm{~Hz}$ QCLS data. In addition to the in situ data, sparser flask measurements from the NOAA Whole Air Sampler (NWAS) are compared in Fig. 12. The axis ranges in Figs. 11 and 12 are the same, with the exception of $\mathrm{N}_{2} \mathrm{O}$, which has large variability from the GC-based measurements. Table 4 summarizes the median differences with NOAA for each of the QCLS species at the mean concentration measured on each of the five HIPPO transects (Table 3). Mean biases calculated over the course of HIPPO are $-112,0.85,1.07$, and $-1.94 \mathrm{ppb}$ for the four species. Only $\mathrm{N}_{2} \mathrm{O}$ falls outside of the estimated uncertainties in the measurements. This is in part due to the recalibration of Primary 4 (cylinder ID ND24118, Table 2a) that deviated from the original value by more than 4 times the $1 \sigma$ NOAA calibration uncertainty. This cylinder falls on the high range of the NOAA $\mathrm{N}_{2} \mathrm{O}$ calibration standards and is only bracketed by one NOAA standard with higher concentration (Hall et al., 2007). Additional $\mathrm{CO}_{2}$ flask data were available from the NCAR/Scripps Medusa flask sampler, which collected air in $1.5 \mathrm{~L}$ glass flasks for analysis in the Scripps Oxygen Laboratory. Table 5 presents the corresponding median differences between QCLS and Medusa at the mean concentration measured on each of the five HIPPO transects. Although the $\mathrm{CO}_{2}$ offsets for individual missions to Scripps are not correlated with the offsets to NOAA, the five-mission average is very similar at $-108 \mathrm{ppb}$.

For CalNex, the payload of the NOAA P-3 aircraft included simultaneous $1 \mathrm{~Hz}$ measurements of $\mathrm{CO}$ using the NOAA VUV spectrometer (Holloway et al., 2000) and $\mathrm{CO}_{2}$ and $\mathrm{CH}_{4}$ using the NOAA/Picarro Cavity Ring-Down Spectrometer (CRDS). The comparisons for all three species are shown in Fig. 13. No additional sensors measured $\mathrm{N}_{2} \mathrm{O}$ 

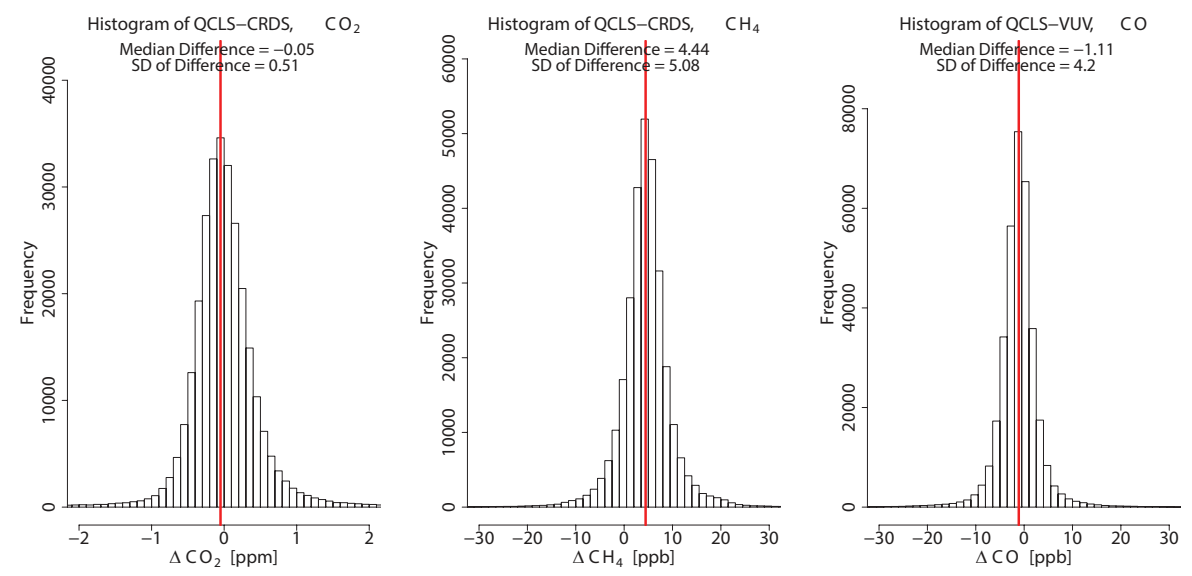

Figure 13. The $1 \mathrm{~Hz}$ CalNex data comparison for QCLS with the NOAA/Picarro CRDS for $\mathrm{CO}_{2}$ (left) and $\mathrm{CH}_{4}$ (middle) as well as the comparison with the NOAA VUV sensor for CO (right).

during CalNex. The CRDS made $1 \mathrm{~Hz}$ measurements of $\mathrm{CO}_{2}$ and $\mathrm{CH}_{4}$ with $1 \mathrm{~s}$ RMS precisions of 100 and $1.5 \mathrm{ppb}$, respectively (Peischl et al., 2012). Both sets of measurements were independently calibrated to NOAA standards during flight, accounting for roughly $20 \%$ of the sampling duty cycle for each instrument. The QCLS and CRDS $\mathrm{CO}_{2}$ data agreed well with one another, with a mean difference of $0.05 \mathrm{ppm}$ and standard deviation of 0.51 over 130 flight hours of sampling, similar to the QCLS and OMS comparison on HIPPO. The mean difference in $\mathrm{CH}_{4}$ was $4.5 \mathrm{ppb}$, more than our estimated uncertainty, with a standard deviation of $5.1 \mathrm{ppb}$. The cause of the $\mathrm{CH}_{4}$ measurement discrepancy has remained a mystery despite extensive efforts to explain the difference. These biases correspond to errors of $0.01 \%$ and $0.25 \%$ for $\mathrm{CO}_{2}$ and $\mathrm{CH}_{4}$, respectively, using background concentrations of $390 \mathrm{ppm}$ and $1800 \mathrm{ppb}$. The bias between the independent $\mathrm{CO}$ sensors was $1.1 \mathrm{ppb}$ during CalNex. It should be noted that the NOAA VUV CO sensor did not dry the ambient air during measurement and reported wet mole fractions. Dilution therefore accounts for some of the bias. The in-flight NOAA VUV CO measurements were calibrated by means of standard additions traceable to NIST with backgrounds determined by catalytically scrubbing $\mathrm{CO}$ from the ambient air sample.

To minimize data gaps in the $1 \mathrm{~Hz}$ flight data over the missions, we fit a loess curve with a $1000 \mathrm{~s}$ span window to calculate the time evolution of the QCLS minus OMS/CRDS/VUV concentration bias. The QCLS data are used as the primary data, and calibration gaps are filled using the sum of the OMS/CRDS/VUV data and the loess bias curve (CO2.X in HIPPO, CO2.X and CH4.X in CalNex, and CO.X in both HIPPO and CalNex). This resulted in an overall mission data retrieval duty cycle of over $95 \%$ for HIPPO and $97 \%$ for CalNex, a significant improvement over the $\sim 78 \%$ duty cycle from QCLS alone. These merge products are denoted CO2.X, CH4.X, and CO.X. A merge product for
$\mathrm{N}_{2} \mathrm{O}$ was not created because no other fast-response $\mathrm{N}_{2} \mathrm{O}$ sensors were available for either mission.

\section{Conclusions}

During the HIPPO and CalNex flight measurement campaigns, we achieved measurement compatibilities with respect to WMO/NOAA scales of $0.03 \%, 0.05 \%, 0.3 \%$, and $2 \%$ for $\mathrm{CO}_{2}, \mathrm{CH}_{4}, \mathrm{~N}_{2} \mathrm{O}$, and $\mathrm{CO}$ relative to background concentrations of $390 \mathrm{ppm}, 1850 \mathrm{ppb}, 325 \mathrm{ppb}$, and $100 \mathrm{ppb}$, respectively, by adequately regulating pressure and temperature and by using a robust in-flight calibration procedure that improves upon spectroscopically calibrated measurements. We report long-term compatibility for $\mathrm{CO}_{2}, \mathrm{CH}_{4}, \mathrm{~N}_{2} \mathrm{O}$, and CO from nearly 450 flight hours of 100, 1, 1.1, and $2 \mathrm{ppb}$, respectively. The data sets generated using the QCLS for HIPPO and CalNex have provided extensive global (HIPPO) and regional (CalNex) coverage and have been useful in many studies to date (Graven et al., 2013; Wunch et al., 2010; Kort et al., 2011, 2012; Wecht et al., 2012; Xiang et al., 2013b; Peischl et al., 2012). We emphasize the importance of in-flight calibrations traceable to WMO/NOAA standards, essential in studies that combine measurements from independent sensors, and present our practices for their implementation.

Acknowledgements. The Harvard QCLS was a joint collaboration with Aerodyne and NCAR, and was funded by NSF as a core instrument on NCAR's Gulfstream V aircraft. We would like to thank all the pilots, aircraft technicians, and support staff of the NCAR HIAPER-GV and NOAA P-3 as well as the many NOAA and NCAR collaborators who made the CalNex and HIPPO measurements possible. This work was supported by the following grants to Harvard University: NASA NNX09AJ94G, NNX11AG47G, and NNX09AU40G, NSF ATM 083091 2, NOAA NA09OAR4310122, and NA11OAR4310158. G. W. Santoni acknowledges support from the NSF Graduate Research Fellowship Program and the 
EPA Science to Achieve Results Fellowship. Sunyoung Park was supported by the Korea Meteorological Administration Research and Development Program under Grant CATER 2012-3010.

Edited by: D. Heard

\section{References}

Akima, H.: A new method of interpolation and smooth curve fitting based on local procedures, J. ACM, 17, 589-602, 1970.

Chen, H., Winderlich, J., Gerbig, C., Hoefer, A., Rella, C. W., Crosson, E. R., Van Pelt, A. D., Steinbach, J., Kolle, O., Beck, V., Daube, B. C., Gottlieb, E. W., Chow, V. Y., Santoni, G. W., and Wofsy, S. C.: High-accuracy continuous airborne measurements of greenhouse gases $\left(\mathrm{CO}_{2}\right.$ and $\left.\mathrm{CH}_{4}\right)$ using the cavity ringdown spectroscopy (CRDS) technique, Atmos. Meas. Tech., 3, 375-386, doi:10.5194/amt-3-375-2010, 2010.

Daube, B. C., Boering, K. A., Andrews, A. E., and Wofsy, S. C.: A high-precision fast-response airborne $\mathrm{CO}_{2}$ analyzer for in situ sampling from the surface to the middle stratosphere, J. Atmos. Ocean. Tech., 19, 1532-1543, 2002.

Dlugokencky, E. J., Myers, R. C., Lang, P. M., Masarie, K. A., Crotwell, A. M., Thoning, K. W., Hall, B. D., Elkins, J. W., and Steele, L. P.: Conversion of NOAA atmospheric dry air $\mathrm{CH}_{4}$ mole fractions to a gravimetrically prepared standard scale, J. Geophys. Res.-Atmos., 110, D18306, doi:10.1029/2005JD006035, 2005.

Elkins, J. W., Moore, F. L., and Kline, E. S.: Update: New Airborne Gas Chromatograph for NASA airborne platforms, Proceedings of the Earth Science Technology Conference, 1-3, 2002.

Fahey, D. W., Churnside, J. H., Elkins, J. W., Gasiewski, A. J., Rosenlof, K. H., Summers, S., Aslaksen, M., Jacobs, T. A., Sellars, J. D., Jennison, C. D., Freudinger, L. C., and Cooper, M.: Altair Unmanned Aircraft System Achieves Demonstration Goals, EOS T. Am. Geophys. Un., 87, 197-201, doi:10.1029/2006EO200002, 2006.

Fried, A., Diskin, G., Weibring, P., Richter, D., Walega, J. G., Sachse, G., Slate, T., Rana, M., and Podolske, J.: Tunable infrared laser instruments for airborne atmospheric studies, Appl. Phys. B, 92, 409-417, 2009.

Gerbig, C., Schmitgen, S., Kley, D., Volz-Thomas, A., Dewey, K., and Haaks, D.: An improved fast-response vacuum-UV resonance fluorescence $\mathrm{CO}$ instrument, J. Geophys Res.-Atmos., 104, 1699-1704, doi:10.1029/1998JD100031, 1999.

Gerbig, C., Lin, J. C., Wofsy, S. C., Daube, B. C., Andrews, A. E., Stephens, B. B., Bakwin, P. S., and Grainger, C. A.: Toward constraining regional-scale fluxes of $\mathrm{CO}_{2}$ with atmospheric observations over a continent: 2. Analysis of COBRA data using a receptor-oriented framework, J. Geophys. Res., 108, 4757, doi:10.1029/2003JD003770, 2003.

Graven, H. D., Keeling, R. F., Piper, S. C., Patra, P. K., Stephens, B. B., Wofsy, S. C., Welp, L. R., Sweeney, C., Tans, P. P., Kelley, J. J., Daube, B. C., Kort, E. A., Santoni, G. W., and Bent, J. D.: Enhanced seasonal exchange of $\mathrm{CO}_{2}$ by northern ecosystems since 1960, Science, 341, 1085-1089, doi:10.1126/science.1239207, 2013

Hall, B. D., Dutton, G. S., and Elkins, J. W.: The NOAA nitrous oxide standard scale for atmospheric observations, J. Geophys. Res.-Atmos., 112, D09305, doi:10.1029/2006JD007954, 2007.
Holloway, J. S., Jakoubek, R. O., Parrish, D. D., Gerbig, C., VolzThomas, A., Schmitgen, S., Fried, A., Wert, B., Henry, B., and Drummond, J. R.: Airborne intercomparison of vacuum ultraviolet fluorescence and tunable diode laser absorption measurements of tropospheric carbon monoxide, J. Geophys. Res. Atmos., 105, 24251-24261, doi:10.1029/2000JD900237, 2000.

Hsu, J. and Prather, M. J.: Global long-lived chemical modes excited in a 3-D chemistry transport model: Stratospheric $\mathrm{N}_{2} \mathrm{O}$, $\mathrm{NO}_{\mathrm{y}}, \mathrm{O}_{3}$, and $\mathrm{CH}_{4}$ chemistry, Geophys. Res. Lett., 37, L07805, doi:10.1029/2009GL042243, 2010.

Jiménez, R., Herndon, S., Shorter, J. H., Nelson, D. D., McManus, J. B., and Zahniser, M. S.: Atmospheric trace gas measurements using a dual quantum-cascade laser mid-infrared absorption spectrometer, Proc. SPIE, 5738, 318-331, doi:10.1117/12.597130, 2005.

Jiménez, R., Park, S., Daube, B. C., McManus, J. B., Nelson, D. D., Zahniser, M. S., and Wofsy, S. C.: A new quantum-cascade laser based spectrometer for high-precision airborne $\mathrm{CO}_{2}$ measurements, WMO/GAW Reports, available at: ftp://ftp.wmo. int/Documents/PublicWeb/arep/gaw/gaw168.pdf, 168, 100-105, 2006.

Kort, E. A., Patra, P. K., Ishijima, K., Daube, B. C., Jimenez, R., Elkins, J., Hurst, D., Moore, F. L., Sweeney, C., and Wofsy, S. C.: Tropospheric distribution and variability of $\mathrm{N}_{2} \mathrm{O}$ : Evidence for strong tropical emissions, Geophys. Res. Lett., 38, L15806, doi:10.1029/2011GL047612, 2011.

Kort, E. A., Wofsy, S. C., Daube, B. C., Diao, M., Elkins, J. W., Gao, R. S., Hintsa, E. J., Hurst, D. F., Jiménez, R., Moore, F. L., Spackman, J. R., and Zondlo, M. A.: Atmospheric observations of Arctic Ocean methane emissions up to $82^{\circ}$ north, Nat. Geosci. 5, 318-321, doi:10.1038/ngeo1452, 2012.

McManus, J. B., Kebabian, P. L., and Zahniser, W. S.: Astigmatic mirror multipass absorption cells for longpath-length-spectroscopy, Appl. Optics, 34, 3336-3348, doi:10.1364/AO.34.003336, 1995.

Miller, S. M., Matross, D. M., Andrews, A. E., Millet, D. B., Longo, M., Gottlieb, E. W., Hirsch, A. I., Gerbig, C., Lin, J. C., Daube, B. C., Hudman, R. C., Dias, P. L. S., Chow, V. Y., and Wofsy, S. C.: Sources of carbon monoxide and formaldehyde in North America determined from high-resolution atmospheric data, Atmos. Chem. Phys., 8, 7673-7696, doi:10.5194/acp-8-7673-2008, 2008.

Moore, F. L., Elkins, J. W., Ray, E. A., Dutton, G. S., Dunn, R. E., Fahey, D. W., McLaughlin, R. J., Thompson, T. L., Romashkin, P. A., Hurst, D. F., and Wamsley, P. R.: Balloonborne in situ gas chromatograph for measurements in the troposphere and stratosphere, J. Geophys Res., 108, 8330, doi:10.1029/2001JD000891, 2003.

NCAR: UCAR, RAF, NCAR HIAPER Modular Inlet - HIMIL, available at: http://www.eol.ucar.edu/ dcrogers/HIAPER/Inlets/ HIMIL/ (last access: 1 July 2013), 2005.

Nelson, D. D., McManus, J. B., Urbanski, S., Herndon, S., and Zahniser, M. S.: High precision measurements of atmospheric nitrous oxide and methane using thermoelectrically cooled midinfrared quantum cascade lasers and detectors, Spectrochim. Acta A, 60, 3325-3335, 2004.

Novelli, P. C., Collins, J. E. J., Myers, R. C., Sachse, G. W., and Scheel, H. E.: Reevaluation of the NOAA/CMDL carbon monoxide reference scale and comparisons with $\mathrm{CO}$ reference gases at 
NASA-Langley and the Fraunhofer Institute, J. Geophys. Res.Atmos., 99, 12833-12839, 1994.

O'Shea, S. J., Bauguitte, S. J.-B., Gallagher, M. W., Lowry, D., and Percival, C. J.: Development of a cavity-enhanced absorption spectrometer for airborne measurements of $\mathrm{CH}_{4}$ and $\mathrm{CO}_{2}$, Atmos. Meas. Tech., 6, 1095-1109, doi:10.5194/amt-6-1095-2013, 2013.

Peischl, J., Ryerson, T. B., Holloway, J. S., Trainer, M., Andrews, A. E., Atlas, E. L., Blake,D. R., Daube, B. C., Dlugokencky, E. J., Fischer, M. L., Goldstein, A. H., Guha, A., Karl, T., Kofler, J., Kosciuch, E., Misztal, P. K., Perring, A. E., Pollack, I. B., Santoni, G. W., Schwarz, J. P., Spackman, J. R., Wofsy, S. C., and Parrish, D. D.: Airborne observations of methane emissions from rice cultivation in the Sacramento Valley of California, J. Geophys. Res., 117, D00V25, doi:10.1029/2012JD017994, 2012.

Rothman, L. S., Gordon, I. E., Barbe, A., Benner, D. C., Bernath, P. E., Birk, M., Boudon, V., Brown, L. R., Campargue, A., Champion, J. P., Chance, K., Coudert, L. H., Dana, V., Devi, V. M., Fally, S., Flaud, J. M., Gamache, R. R., Goldman, A., Jacquemart, D., Kleiner, I., Lacome, N., Lafferty, W. J., Mandin, J. Y., Massie, S. T., Mikhailenko, S. N., Miller, C. E., Moazzen-Ahmadi, N., Naumenko, O. V., Nikitin, A. V., Orphal, J., Perevalov, V. I., Perrin, A., Predoi-Cross, A., Rinsland, C. P., Rotger, M., Simeckova, M., Smith, M. A. H., Sung, K., Tashkun, S. A., Tennyson, J., Toth, R. A., Vandaele, A. C., Vander Auwera, J.: The HITRAN 2008 molecular spectroscopic database, J. Quant. Spectrosc. Ra., 110, 533-572, 2009.

Ryerson, T. B., Andrews, A. E., Angevine, W. M., Bates, T. S., Brock, C. A., Cairns, B., Cohen, R. C., Cooper, O. R., de Gouw, J. A., Fehsenfeld, F. C., Ferrare, R. A., Fischer, M. L., Flagan, R. C., Goldstein, A. H., Hair, J. W., Hardesty, R. M., Hostetler, C. A., Jimenez, J. L., Langford, A. O., McCauley, E., McKeen, S. A., Molina, L. T., Nenes, A., Oltmans, S. J., Parrish, D. D., Pederson, J. R., Pierce, R. B., Prather, K., Quinn, P. K., Seinfeld, J. H., Senff, C. J., Sorooshian, A., Stutz, J., Surratt, J. D., Trainer, M., Volkamer, R., Williams, E. J., and Wofsy, S. C.: The 2010 California Research at the Nexus of Air Quality and Climate Change (CalNex) field study, J. Geophys. Res., 118, 58305866, doi:10.1002/jgrd.50331, 2012.

Schwarz, J. P., Spackman, J. R., Gao, R. S., Watts, L. A., Stier, P., Schulz, M., Davis, S. M., Wofsy, S. C., and Fahey, D. W.: Global-scale black carbon profiles observed in the remote atmosphere and compared to models, Geophys. Res. Lett., 37, L18812, doi:10.1029/2010GL044372, 2010.

Tohjima, Y., Katsumata, K., Morino, I., Mukai, H., Machida, T., Akama, I., Amari, T., and Tsunogai, U.: Theoretical and experimental evaluation of the isotope effect of NDIR analyzer on atmospheric $\mathrm{CO}_{2}$ measurement, J. Geophys. Res.-Atmos., 114, D13302, doi:10.1029/2009JD011734, 2009.

Wecht, K. J., Jacob, D. J., Wofsy, S. C., Kort, E. A., Worden, J. R., Kulawik, S. S., Henze, D. K., Kopacz, M., and Payne, V. H.: Validation of TES methane with HIPPO aircraft observations: implications for inverse modeling of methane sources, Atmos. Chem. Phys., 12, 1823-1832, doi:10.5194/acp-12-1823-2012, 2012.

Werle, P., Mucke, R., and Slemr, F.: The limits of signal averaging in atmospheric trace-gas monitoring by tunable diode-laser absorption spectroscopy (TDLAS), Appl. Phys. B, 57, 131-139, doi:10.1007/BF00425997, 1993.
Wofsy, S. C., the HIPPO Science Team, and Cooperating Modellers and Satellite Teams: HIAPER Pole-to-Pole Observations (HIPPO): Fine grained, global scale measurements for determining rates for transport, surface emissions, and removal of climatically important atmospheric gases and aerosols, Philos. T. Roy. Soc. A, 369, 2073-2086, 2011.

Wunch, D., Toon, G. C., Wennberg, P. O., Wofsy, S. C., Stephens, B. B., Fischer, M. L., Uchino, O., Abshire, J. B., Bernath, P., Biraud, S. C., Blavier, J.-F. L., Boone, C., Bowman, K. P., Browell, E. V., Campos, T., Connor, B. J., Daube, B. C., Deutscher, N. M., Diao, M., Elkins, J. W., Gerbig, C., Gottlieb, E., Griffith, D. W. T., Hurst, D. F., Jiménez, R., Keppel-Aleks, G., Kort, E. A., Macatangay, R., Machida, T., Matsueda, H., Moore, F., Morino, I., Park, S., Robinson, J., Roehl, C. M., Sawa, Y., Sherlock, V., Sweeney, C., Tanaka, T., and Zondlo, M. A.: Calibration of the Total Carbon Column Observing Network using aircraft profile data, Atmos. Meas. Tech., 3, 1351-1362, doi:10.5194/amt3-1351-2010, 2010.

Xiang, B., Nelson, D. D., McManus, J. B., Zahniser, M. S., and Wofsy, S. C.: Towards a stable and absolute atmospheric carbon dioxide instrument using spectroscopic null method, Atmos. Meas. Tech., 6, 1611-1621, doi:10.5194/amt-6-1611-2013, 2013a.

Xiang, B., Miller, S. M., Kort, E. A., Santoni, G. W., Daube, B. C., Commane, R., Angevine, W. M., Ryerson, T. B., Trainer, M. K., Andrews, A. E., Nehrkorn, T., Tian, H., and Wofsy, S. C.: Nitrous oxide $\left(\mathrm{N}_{2} \mathrm{O}\right)$ emissions from California based on 2010 CalNex airborne measurements, J. Geophys. Res.-Atmos., 118, 2809-2820, doi:10.1002/jgrd.50189, 2013b.

York, D., Evensen, N. M., Martinez, M. L., and Delgado, J. D. B.: Unified equations for the slope, intercept, and standard errors of the best straight line, Am. J. Phys., 72, 367, doi:10.1119/1.1632486, 2004.

Zahniser, M. S., Nelson, D. D., McManus, J. B., and Kebabian, P. L.: Measurement of Trace Gas Fluxes Using Tunable DiodeLaser Spectroscopy, Philos. T. Roy. Soc. London A, 351, 371381, 1995.

Zahniser, M. S., Nelson, D. D., McManus, J. B., Herndon, S. C., Wood, E. C., Shorter, J. H., Lee, B. H., Santoni, G. W., Jimenez, R., Daube, B. C., Park, S., Kort, E. A., and Wofsy, S. C.: Infrared QC laser applications to field measurements of atmospheric trace gas sources and sinks in environmental research: enhanced capabilities using continuous wave QCLs, P. SPIE - The International Society for Optical Engineering, 7222, doi:10.1117/12.815172, 2009.

Zare, R. N., Kuramoto, D. S., Haase, C., Tan, S. M., Crosson, E. R., and Saad, N. M. R.: High-precision optical measurements of ${ }^{13} \mathrm{C} /{ }^{12} \mathrm{C}$ isotope ratios in organic compounds at natural abundance, P. Natl. Acad. Sci. USA, 106, 10928-10932, doi:10.1073/pnas.0904203106, 2009.

Zhao, C. L. and Tans, P. P.: Estimating uncertainty of the WMO mole fraction scale for carbon dioxide in air, J. Geophys. Res.Atmos., 111, D08S09, doi:10.1029/2005JD006003, 2006.

Zhao, C., Andrews, A. E., Bianco, L., Eluszkiewicz, J., Hirsch, A., MacDonald, C., Nehrkorn, T., and Fischer, M. L.: Atmospheric inverse estimates of methane emissions from Central California, J. Geophys. Res., 114, D16302, doi:10.1029/2008JD011671, 2009. 